\section{OAK RIDGE K-25 SITE}

MARTIN MARUETIA

\section{CYLINDER YARD INSPECTIONS AND CORRECTIVE ACTIONS}

\author{
C. R. Barlow \\ K. T. Ziehlke \\ W. A. Pryor
}

\section{MANAGED BY}

MARTIN MARIETTA ENERGY SYSTEMS, INC.

FOR THE UNITED STATES

DEPARTMENT OF ENERGY 


\section{DISCLAIMER}

This report was prepared as an account of work sponsored by an agency of the United States Government. Neither the United States Government nor any agency thereof, nor any of their employees, makes any warranty, express or implied, or assumes any legal liability or responsibility for the accuracy, completeness, or usefulness of any information, apparatus, product, or process disclosed, or represents that its use would not infringe privately owned rights. Reference herein to any specific commercial product, process, or service by trade name, trademark, manufacturer, or otherwise, does not necessarily constitute or imply its endorsement, recommendation, or favoring by the United States Government or any agency thereof. The views and opinions of authors expressed herein do not necessarily state or reflect those of the United States Government or any agency thereof. 
$\mathrm{K} / \mathrm{SS}-546$

\title{
CYLINDER YARD INSPECTIONS AND CORRECTIVE ACTIONS
}

\author{
C. R. Barlow \\ Martin Marietta Energy Systems, Inc. \\ K. T. Ziehlke \\ MJB Technical Associates \\ W. A. Pryor \\ PAI
}

Date Published-July 31, 1990

\author{
Prepared by the \\ Oak Ridge Gaseous Diffusion Plant \\ Oak Ridge, Tennessee 37831-7101 \\ operated by \\ MARTIN MARIETTA ENERGY SYSTEMS, INC. \\ for the \\ U.S. DEPARTMENT OF ENERGY \\ under contract DE-AC05-84OR21400




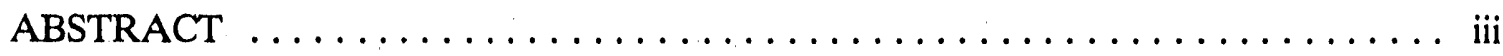

INTRODUCTION $\ldots \ldots \ldots \ldots \ldots \ldots \ldots \ldots \ldots \ldots \ldots \ldots \ldots \ldots \ldots$

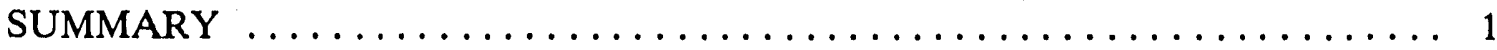

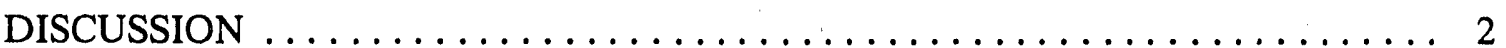

ADDITIONAL VALVE OBSERVATIONS ................. 2

REPLACEMENT OF DEFECTIVE VALVES $\ldots \ldots \ldots \ldots \ldots \ldots \ldots \ldots \ldots$

CYLINDER YARD UPGRADING $\ldots \ldots \ldots \ldots \ldots \ldots \ldots \ldots \ldots \ldots \ldots$

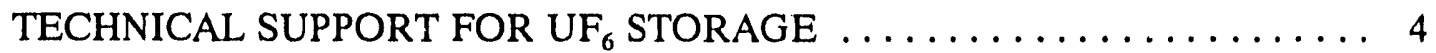

APPENDIX A. SUMMARY OF INSPECTION RESULTS AT K-25 . . . . . . 15

APPENDIX B. FOLLOW-UP ACTIVITIES ON CYLINDER YARD

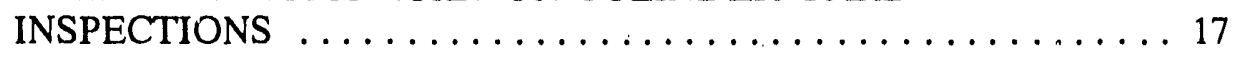

APPENDIX C. BRIEFING TO DOE ON CYLINDER YARD INSPECTIONS $\ldots . .21$ 


\begin{abstract}
Inspection of valves on stored uranium hexafluoride $\left(\mathrm{UF}_{6}\right)$ cylinders was initiated at the three diffusion plant sites in Oak Ridge, Tennessee, Paducah, Kentucky, and Portsmouth, Ohio as the result of the discovery of valve defects and evidence of valve leaks at the Oak Ridge K-25 plant. The coordinated inspection culminated in the identification of additional factors related to long-term safe storage of $U F_{6}$, and plans for correction of such deficiencies are presently being developed and implemented. These corrective actions supplement existing programs aimed at assurance of safe storage as summarized in the report.
\end{abstract}




\section{INTRODUCTION}

In a mini-audit of the K-1066-E cylinder storage yard on May 30, 1990, green deposits were found on a valve body and packing nut, accompanied by unusual, severe corrosion of the packing nut and valve stem (Fig. 1). The audit was conducted as an aid in planning for long-term corrosion monitoring of cylinder steels. Other evidence of valve leakage included corrosion and staining of the cylinder head below the valve and a stained and pitted area on the concrete pad in the drip area below the valve (Fig. 2). Further visual examinations indicated several more valves which exhibited evidence of less extensive leakage (Fig. 3) and one valve where removal of the port cap resulted in discharge of several milliliters of water containing uranium salts in solution. These findings were disseminated to the diffusion plants management, and to the Department of Energy (DOE) and resulted in a full-scale inspection for valve conditions in all cylinder storage areas at enrichment plant sites.

This inspection was completed* and resulted in discovery and documentation at the Oak Ridge plant of 195 valves which gave evidence of present or past leakage as indicated by radioactivity levels above plant-allowable limits, either as alpha count on the valves themselves or as transferrable alpha or beta/gamma in a wipe sample. The valves were also inspected for other defects, such as cracked packing nuts, missing (or cracked) port caps, bent or sheared valve stems, bent valve bodies (illustrated in Figs. 4 through 9), and any other conditions that could affect the integrity of storage-containment or transfer capability.

A corrective action plan and schedule were developed ${ }^{\dagger}$ as a result of the inspection observations that includes (1) decontamination of leaking valves to furnish a starting point for continuing observations for possible leakage; (2) a safety review, operator training, and equ ipment assembly for valve changeout and cylinder burping; and (3) a program for replacing defective valves and defective or missing valve parts. This plan for immediate and near-term corrective actions also requires an evaluation of the need for restacking some cylinders in contact with the ground where corrosion of cylinder walls could be accelerated, and an inspection for pitting corrosion which might affect transfer capability, transportability, or containment integrity.

\section{SUMMARY}

A recent in-house audit of a $\mathrm{UF}_{6}$ cylinder storage yard at the Oak Ridge $\mathrm{K}-25$ plant revealed indications of valve leakage and a resulting severely corroded valve stem and cracked packing nuts and port caps. The survey results were reported to management at the gaseous diffusion plants, and inspections of all cylinders in storage were initiated at the three sites. Corrective actions have been planned and are being executed, and

*See Appendix A. Holes were discovered in two storage cylinders during inspection at the Portsmouth, Ohio, plant and are being investigated separately by an appointed committee.

${ }^{\dagger}$ See Appendix B. 
recommendations for maintaining safe storage conditions address periodic inspections for conditions of valves, plugs, and cylinder-wall corrosion. Storage upgrading to permit plug-end inspection and wall-thickness measurements will require cylirder restacking, which will afford opportunities for replacement of corrosion-enhancing wooden chocks, for identifying and disposing of cylinders damaged by on-ground corrosion in earlier storage experience, and for cleaning and painting cylinders to fit them for truly long term storage with minimized requirements for surveillance.

High-volume air monitoring for uranium by K-25 Health Physics and air sampling for hydrogen fluoride (HF) by environmental personnel during valve inspection, decontamination, and sampling activities gave no indications of active material releases. However, periodic monitoring of this type, along with provisions for soil and drainage runoff sampling, can furnish added assurance of saie storage through enhancing the sensitivity of early leak detection in the cylinder yards. Other programs directed toward improving the safety and reliability of long-term $\mathrm{UF}_{6}$ storage are in place and have been functioning for some time. Currently these include

1. A study of disposition options for depleted feed materials.

2. A cylinder-yard corrosion-monitoring program and cylinder life-cycle study.

3. A rupture test program whose object is to assess the safety of present cylinder designs and of damaged or defective cylinder conditions.

4. Safety-analysis reviews of cylinder storage activities.

\section{DISCUSSION}

\section{ADDITIONAL VALVE OBSERVATIONS*}

For purposes of the survey, leaking valves were defined as those where visible deposits had radioactivity levels in excess of plant allowable limits. It was not possible, however, to distinguish active leaks from past (or dormant) leaks, either on the basis of activity levels or by the character or color of the deposits, which showed a full range of colors from bright yellow through deep green or blue-green. Chemical analysis of deposits showed the yellow materials to be composed of uranium compounds only, while the green materials also contained large amounts of copper, in addition to the uranium compounds, indicating that their source was corrosion of bronze (or Monel) valve parts. It was not possible to distinguish between the green and the yellow, deposits solely on the basis of their uranium cor tents, and it would appear that all such deposits on the valves signify leakage of $\mathrm{UF}_{6}$ from ihe cylinder. The yellow uranium-only deposits result from reaction with moist air and dissipation of the HF product, and the uranium-copper deposits show corrosion of the bronze valve parts by the HF product of the leaking $\mathrm{UF}_{6}$. To identify actively leaking valves, deposits will be removed from the contaminated valves identified by Health Physics measurements, and the cleaned valves will be covered with a clear, nonreactive bag of a fluorinated plastic (Teflon) material. Continuing leakage of $\mathrm{UF}_{6}$ will be made evident by the presence of decomposition products (mainly $\mathrm{UO}_{2} \mathrm{~F}_{2}$ ) on the inner surfaces of the bag, to be determined at a later date by visual inspection of the covered valves. Following a

*Appendix B, items 1 through 5. 
pressure check to verify cylinder internal pressure conditions, the valves will be retorqued to specifications, and new bags will be installed. If a second inspection indicates continuing leakage, the valves will be replaced with new valves.

A yearly visual inspection for indications of valve leakage is to be conducted on all cylinders in storage at K-25. Visual indications of discoloration will be verified, monitored, and corrected as outlined above.

\section{REPLACEMENT OF DEFECTIVE VALVES*}

Planning is under way for assembly of an equipment cart which will give an acceptable level of control for field valve exchanges. This will require a high-efficiency particulate air vacuum cleaner, a pressure/vacuum gage for attachment to a cylinder valve, a vacuum pump (or surge volume capability) with associated chemical traps, and the hand tools required for valve manipulation, repair, and replacement. In association with the preparation of this equipment cart, a safety review is to be conducted for valve changeout and cylinder burping, along with preparation of the necessary procedures and the required operator training. The equipment, procedures, and developed operator skills will not only be utilized in correcting the deficiencies noted in the audit but will provide the plant with a long-term capability for maintaining safe cylinder storage.

\section{CYLINDER YARD UPGRADING}

Nearly all of the K-25 storage facilities depend on contoured wooden saddles to maintain adequate ground clearance for ensuring good drainage and generally dry storage conditions. The wooden supports are porous, however, and absorb moisture in wet weather, retaining it for relatively long periods when the rest of the cylinder surfaces are dry. This extended presence of moisture results in localized pitting activity in the saddle contact areas, and when cylinders are moved, these pitted areas are readily apparent. Cylinder storage at the Portsmouth and Paducah Gaseous Diffusion Plants is phasing out wooden saddles and substituting cast concrete or steel supports which drain and dry more readily in order to eliminate a potential source of accelerated corrosion. It is recommended that such a program be adopted for the K-25 storage facilities and be implemented in coordination with any other cylinder-moving requirements.

In addition to the valve inspection which grew out of the previously mentioned miniaudit of K-1066-E, DOE also requested an examination for plug-end conditions. This examination could not be made in the same detail as was exercised in the valve inspections, since many cylinder storage arrays do not allow access to the plug ends of cylinders. The primary requirement in the original cylinder storage efforts was that the nameplate would be accessible for inventory purposes, and the double-row arrangement often gave plug-end clearances of $<1 \mathrm{ft}$. Only a few storage areas allow walk-through space; a few more permit limited visual access to the plug end of the cylinder. Access is similarly limited to cylinder side-wall areas for purposes of thickness measurements. While some surfaces are accessible for instrument probe contact for ultrasonic measurement of thickness, it is not likely that

*Appendix B, items 6, 7, and 8. 
pitted cylinders which had earlier been in contact with the ground (Fig. 10) can be discovered in this manner. Such cylinders can only be identified through visual inspection and spot ultrasonic measurements during restacking operations.

It is thus evident that any long.term storage program at $\mathrm{K}-25$ will require restacking of all cylinders. Preparations for such a prog am should include an engineering evaluation of each of the storage yards for suitability of the paved surface to support the cylinder loads, provisions for environmental monitoring/sampling of drainage run-off, and procurement or fabrication of a suitable number of concrete chocks. The stacking geometry should provide for full walk-through access to both ends of each cylinder. At the time the cylinders are moved for restacking, it is strongly recommended that they be painted to halt degradation due to atmospheric corrosion. Such painting should te done on a surface that has been suitably prepared by grit blasting to remove accumulated oxides. A zinc-rich paint which will furnish some degree of galvanic protection in areas of handling or stacking damage is preferred for this application and can be expected to remain functional for 25 years or more.

\section{TECHNICAL SUPPORT FOR UF 6 STORAGE}

The current program for monitoring cylinder storage yards includes a yearly observation cycle for valve conditions and periodic measurement of wall thickness on selected cylinders. Health Physics and Environmental monitoring of air samples showed no dispersion of radioactive or toxic materials during the current survey; this type of sampling should be continued on a regular basis and should be extended to include some level of monitoring of soil samples and of rainwater run-off from the storage yards.

With these additions, the K-25 plant storage program will be in substantial compliance with the program controls to be recommended in the upcoming Rev. 6, ORO651 and with a soon-to-be-issued Guidebook to Safe Production, Transportation, Handling and Storage of $U F_{6}$ of the International Atomic Energy Agency. 
PHOTONOKK/PH.90.1715

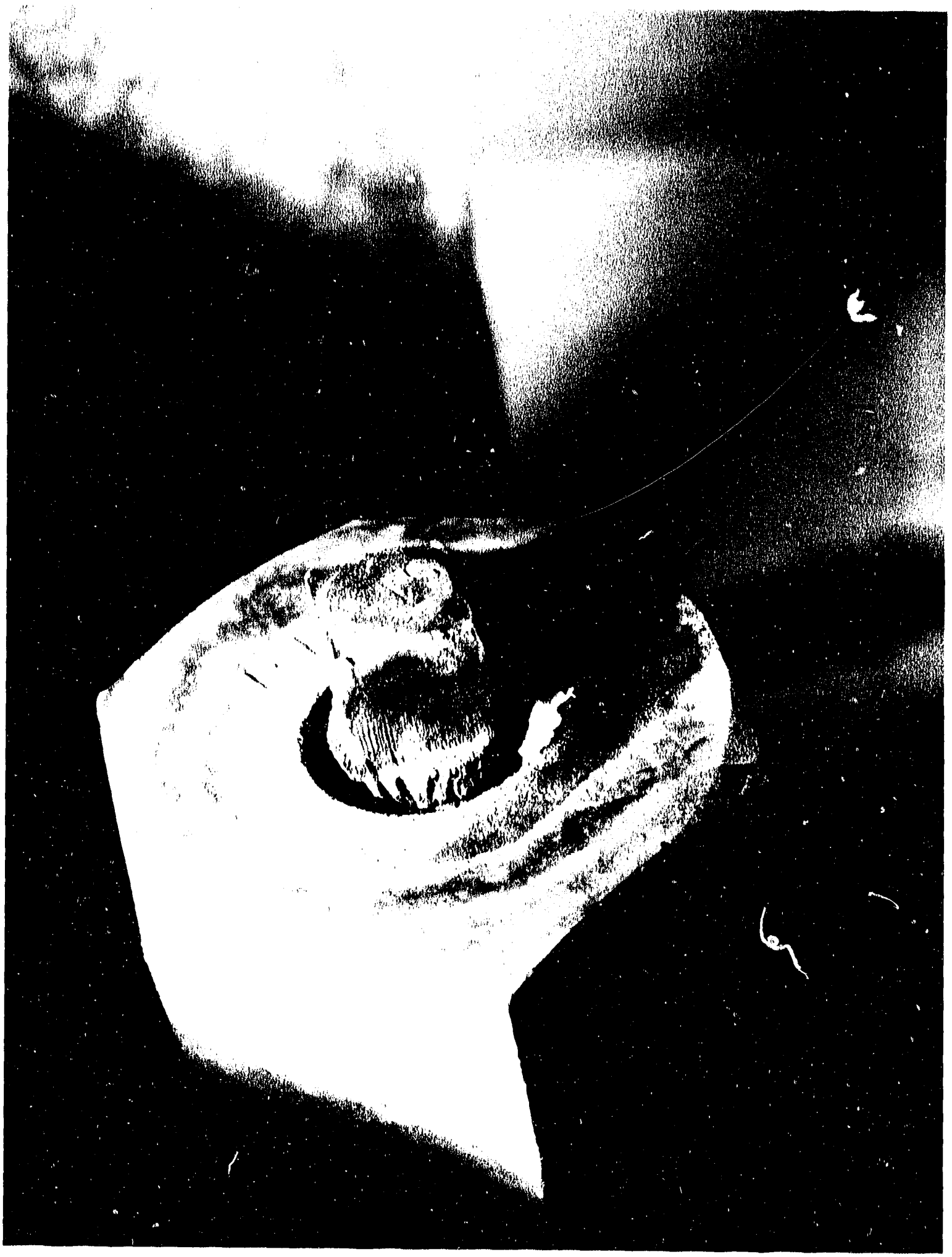

Figure 1

(ORRODLD VALVE IN K-1066ESTORAGE YARD 


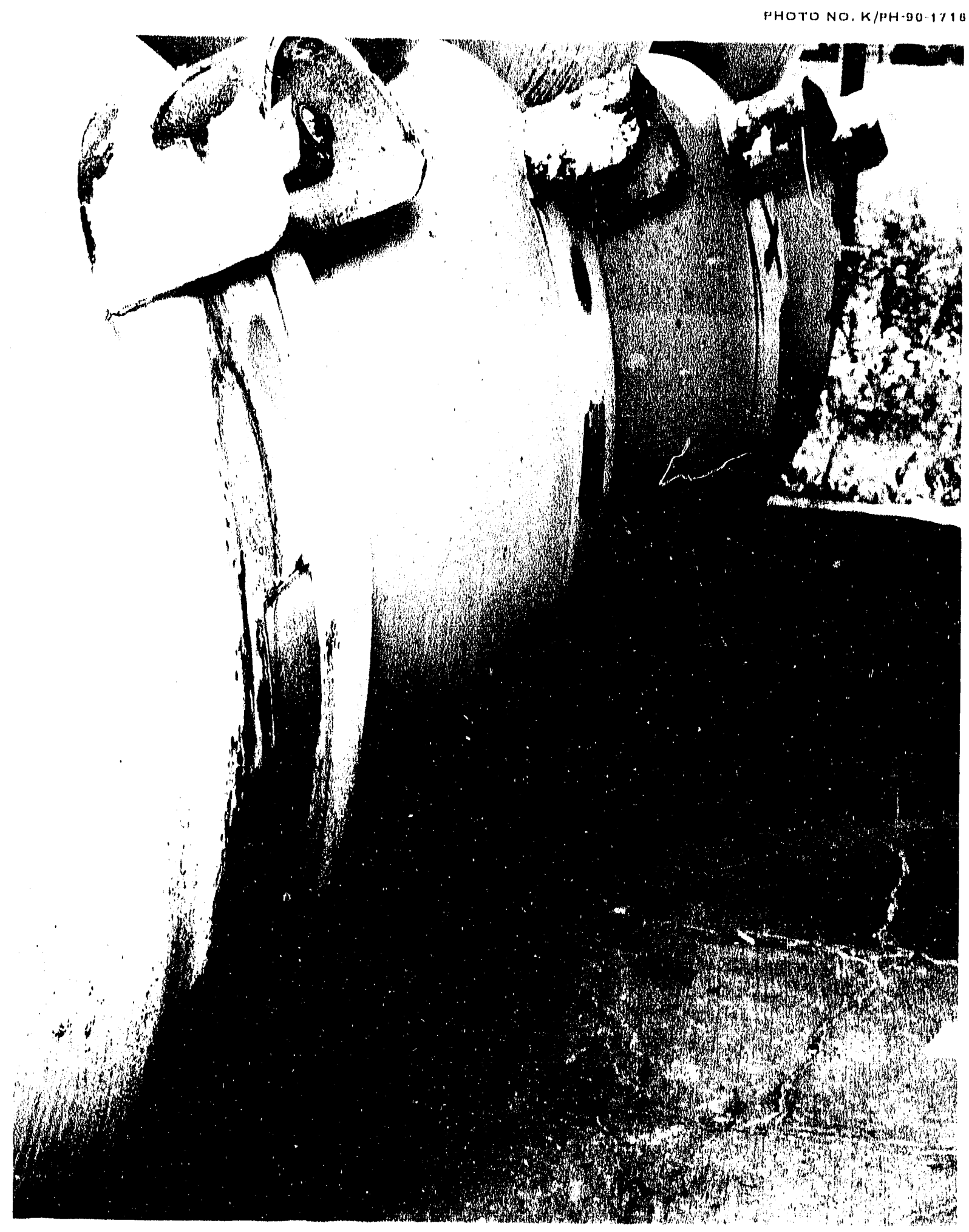

Figure ?

EVIDENCE OF LEAKAGE BELOW CORRODED VAIVH Note also the etched area on the concrete pad. 


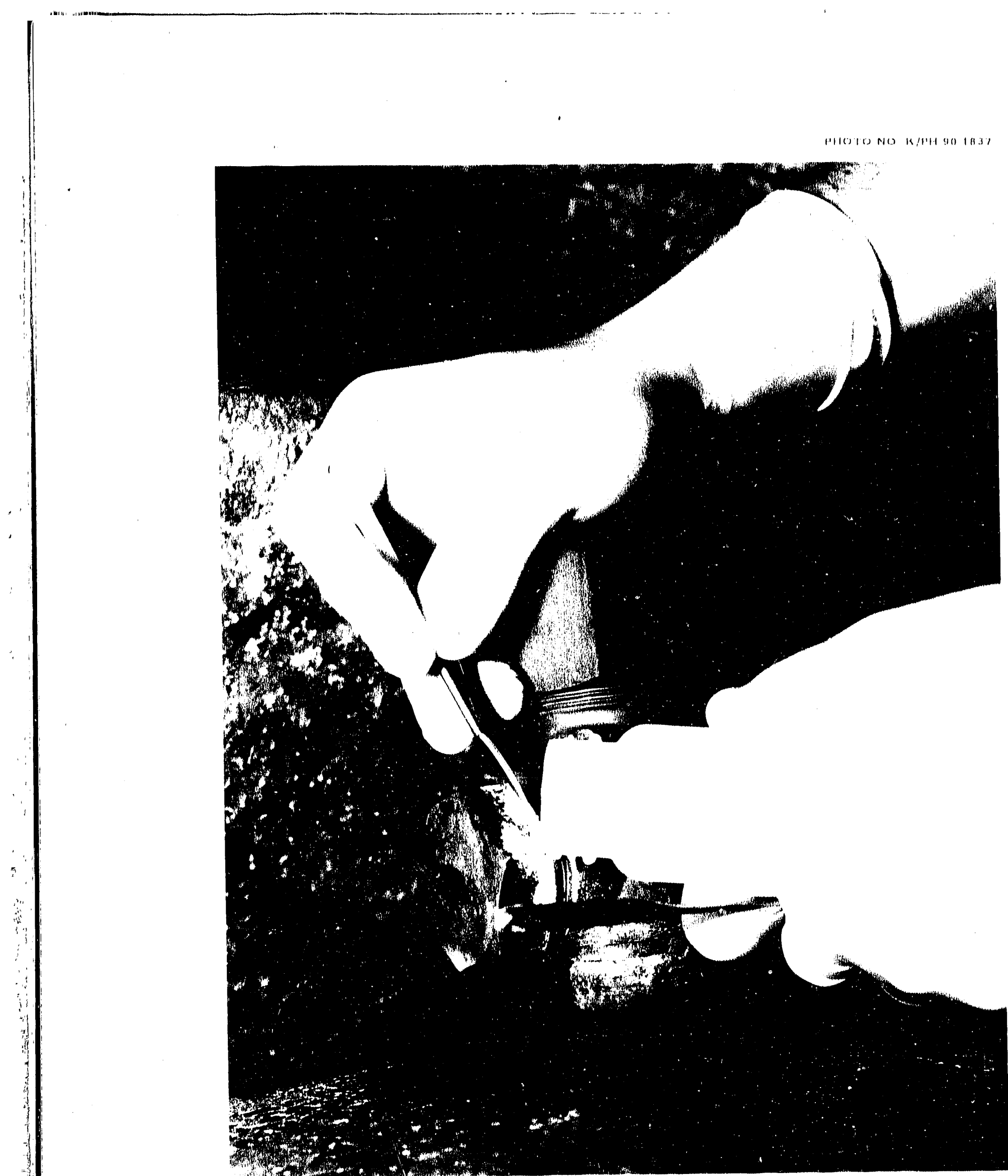

figme?

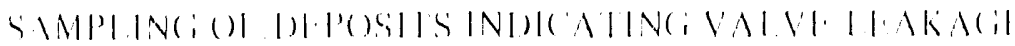


PHOTO NO, K/PH-90.1710

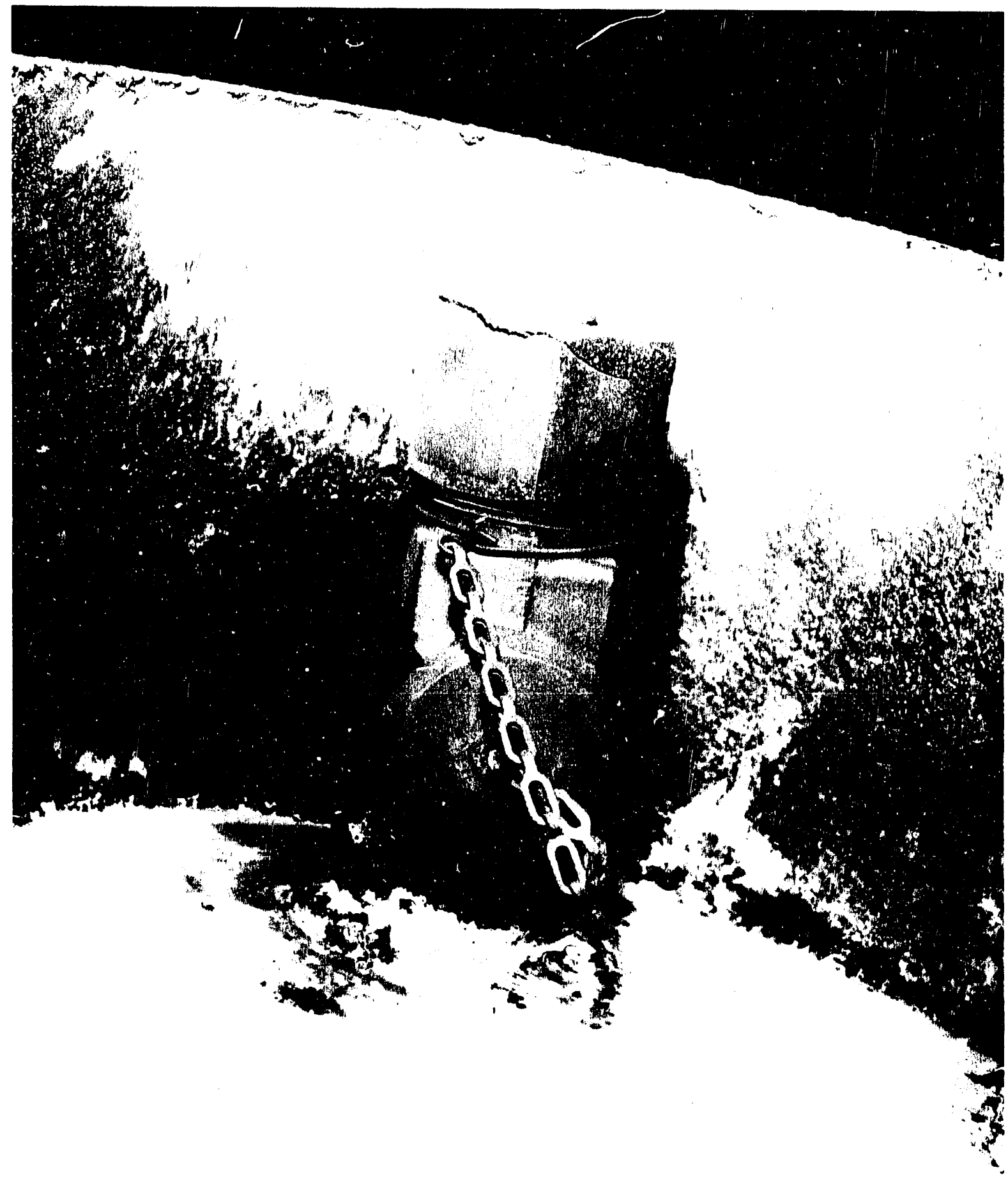

Finure t

( RAC'KFI) PACKINGNUI 
PHOTO NO.K/PH.90.1875

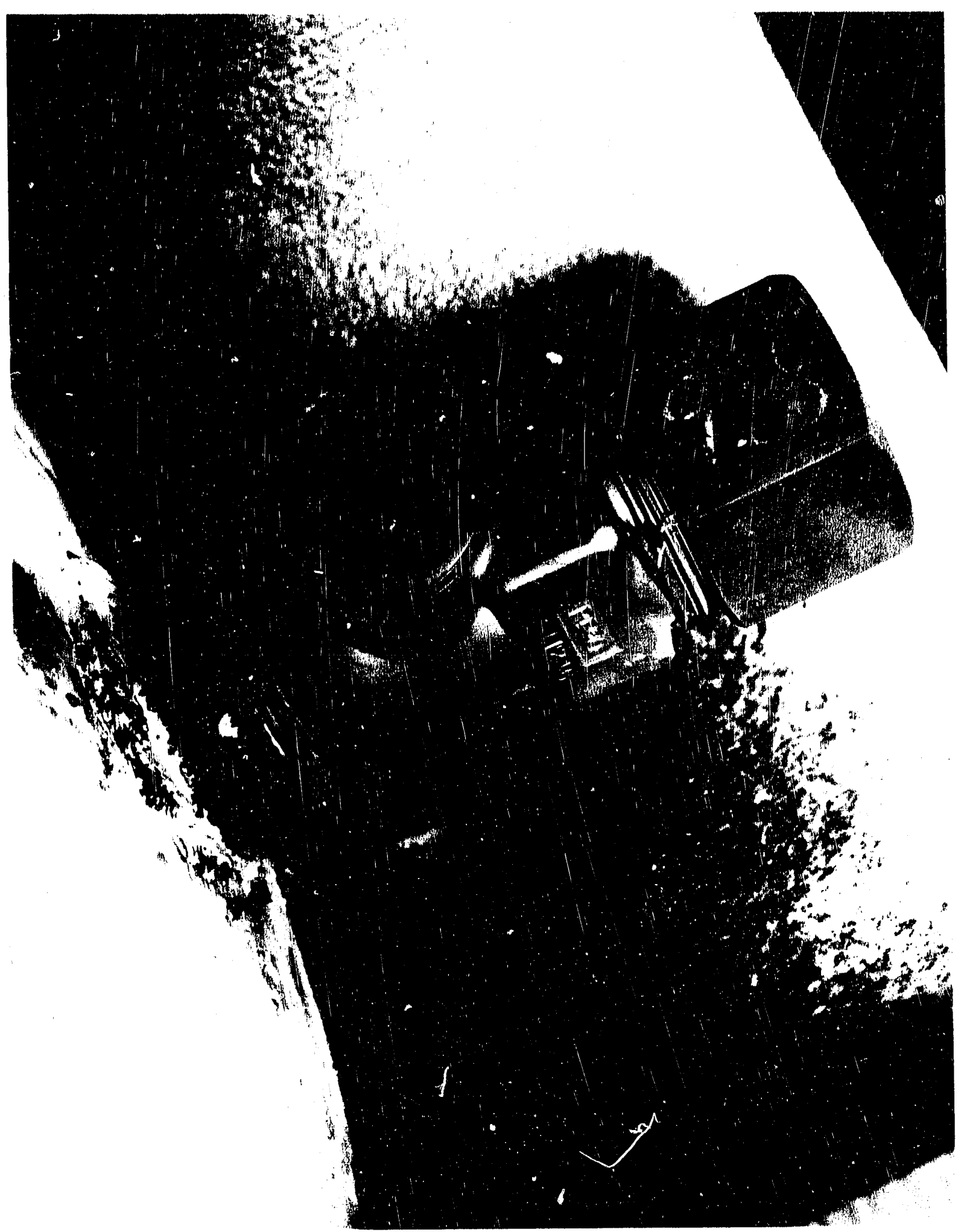

Figure 5

( RACKED) POR'T CAP 


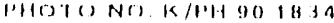

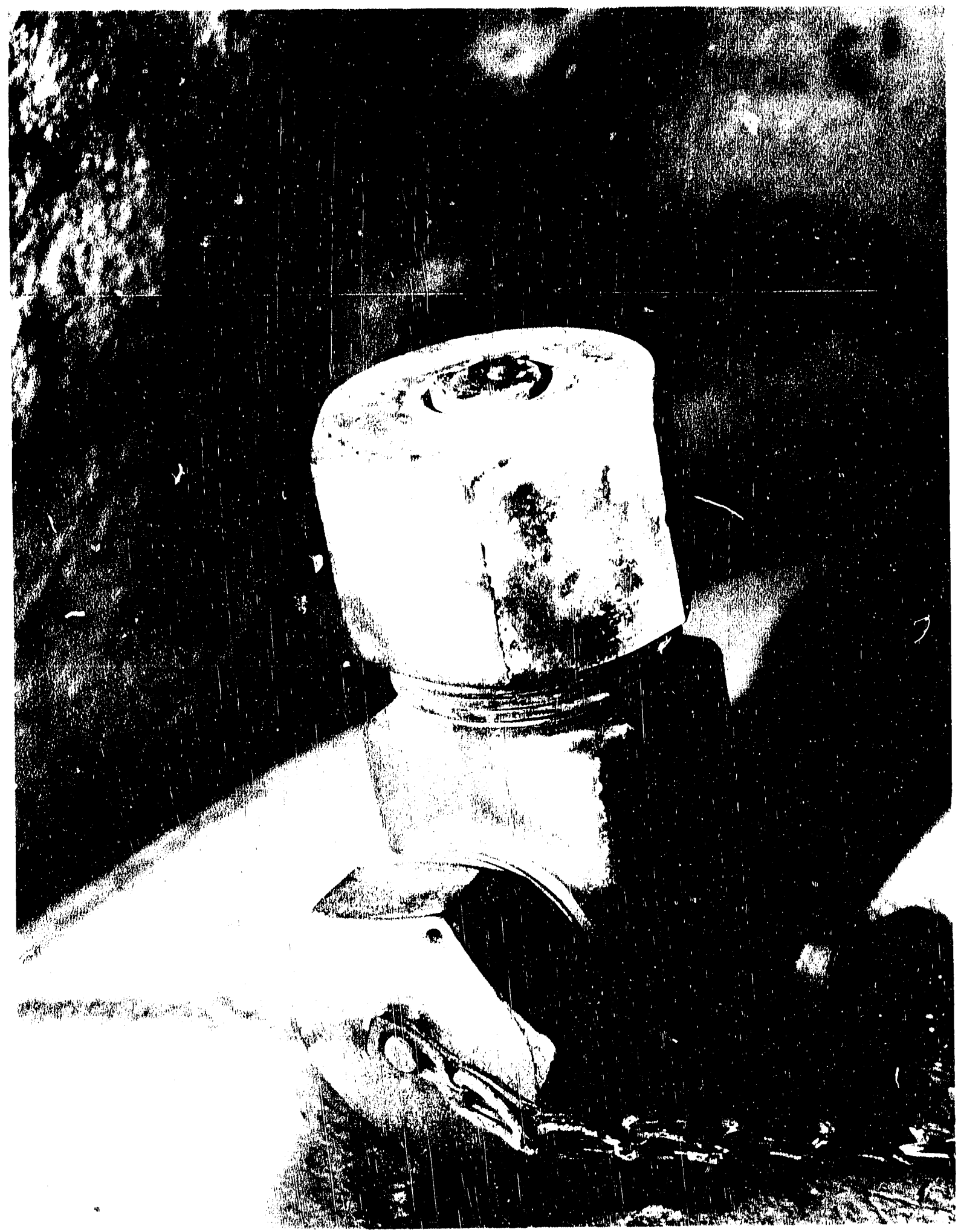

Figure 6

SHIARHDVAIVISSHM 


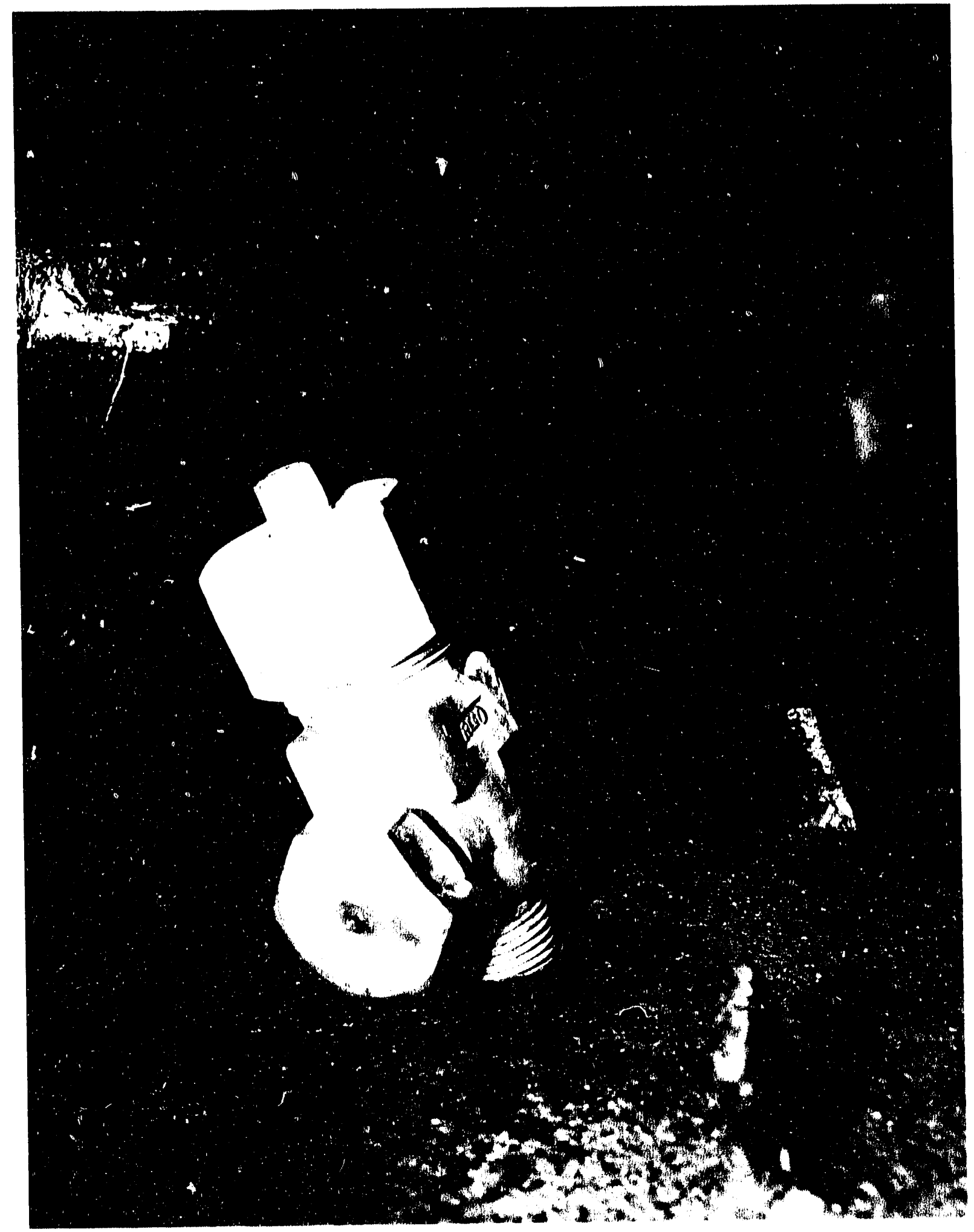

I119!11

BI VI V'AIVI 


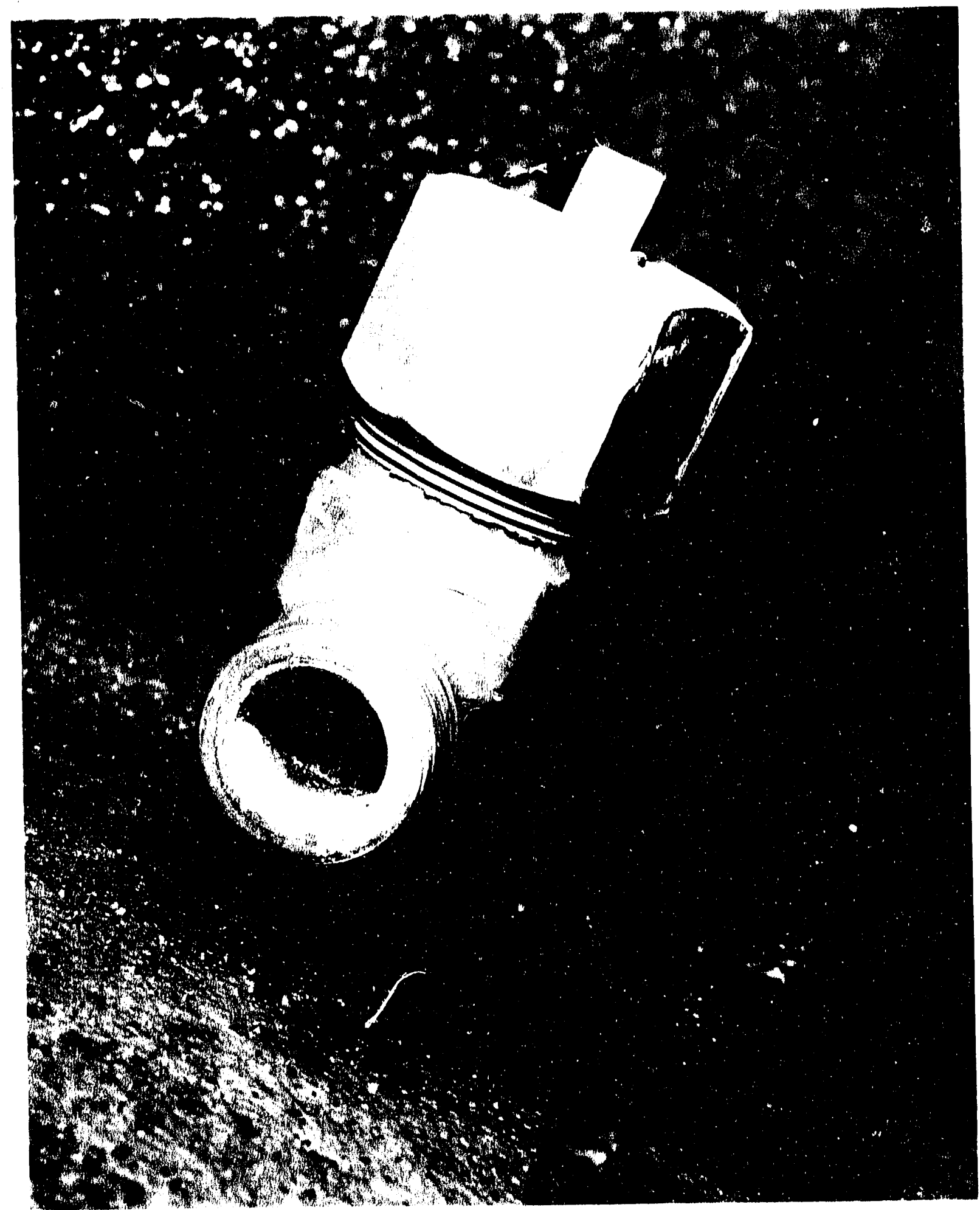

Figutio is

MISSING I'ORI ( AP'

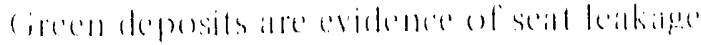


PHO 10 NO. K/PH $001 / 24$

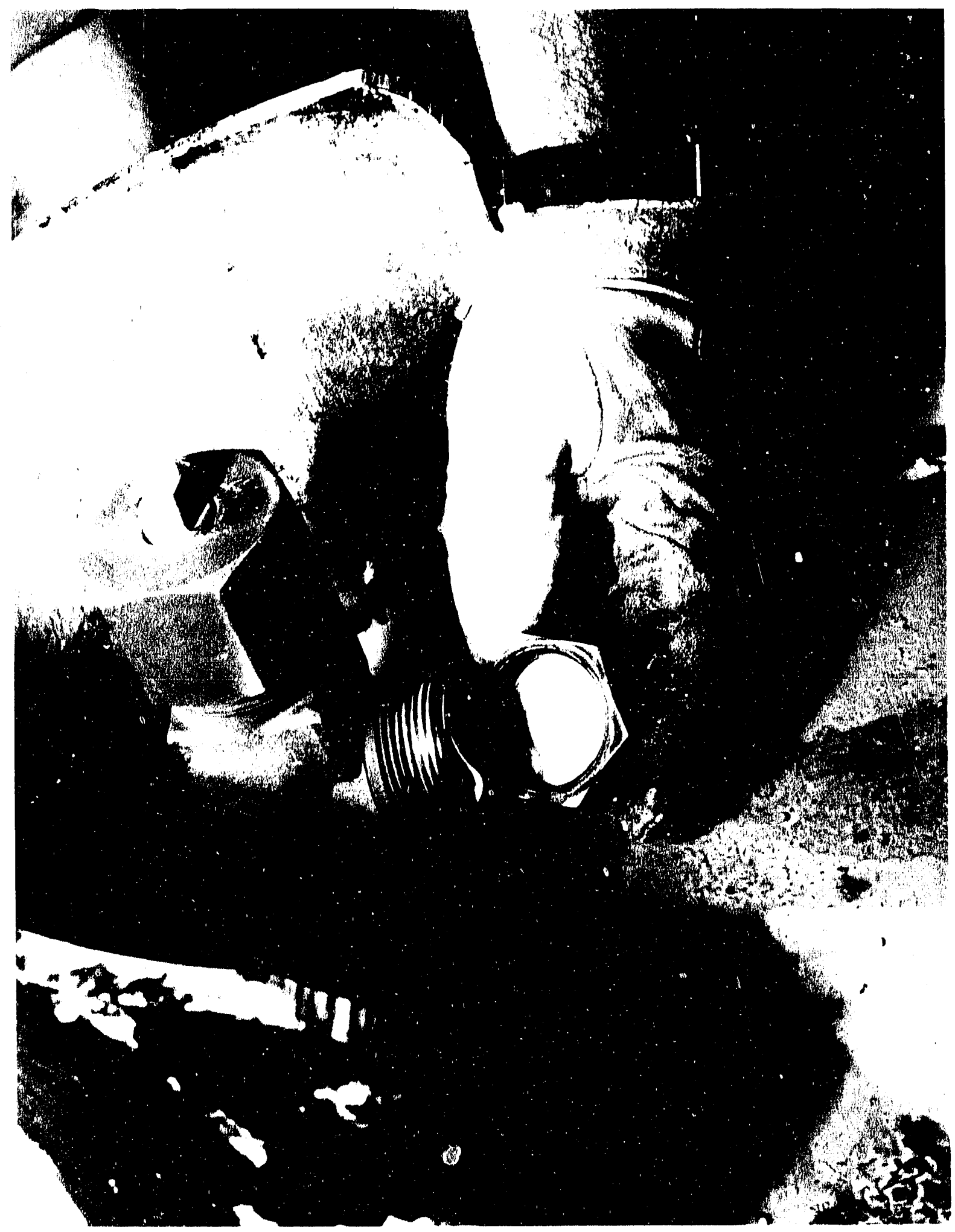

Figure 9)

PORI (AP REMOVAL SHOWS TRAPPII) WATHR 
PHO 10 NO, K/11H!IO 1841

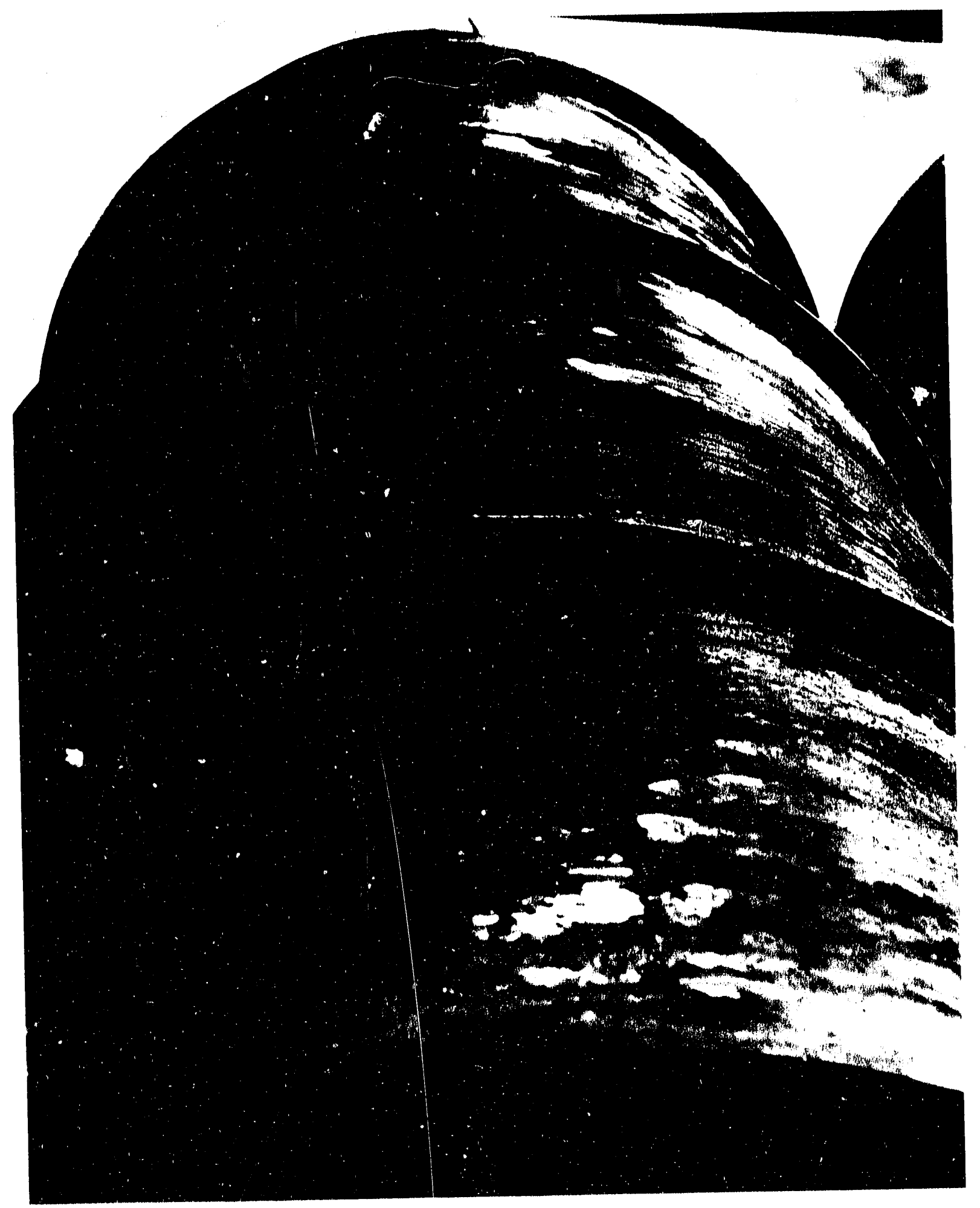

rigure 10

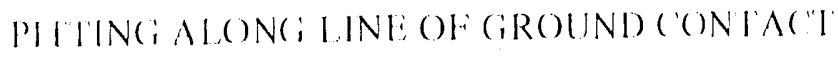

A minimum thickness of 0.203 inches wals ohererved. 
APPENDIX A

SUMMARY OF INSPECTION RESULTS AT K-25 


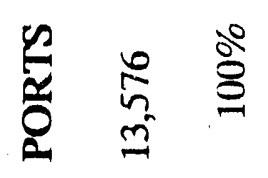

$50=98$

苋

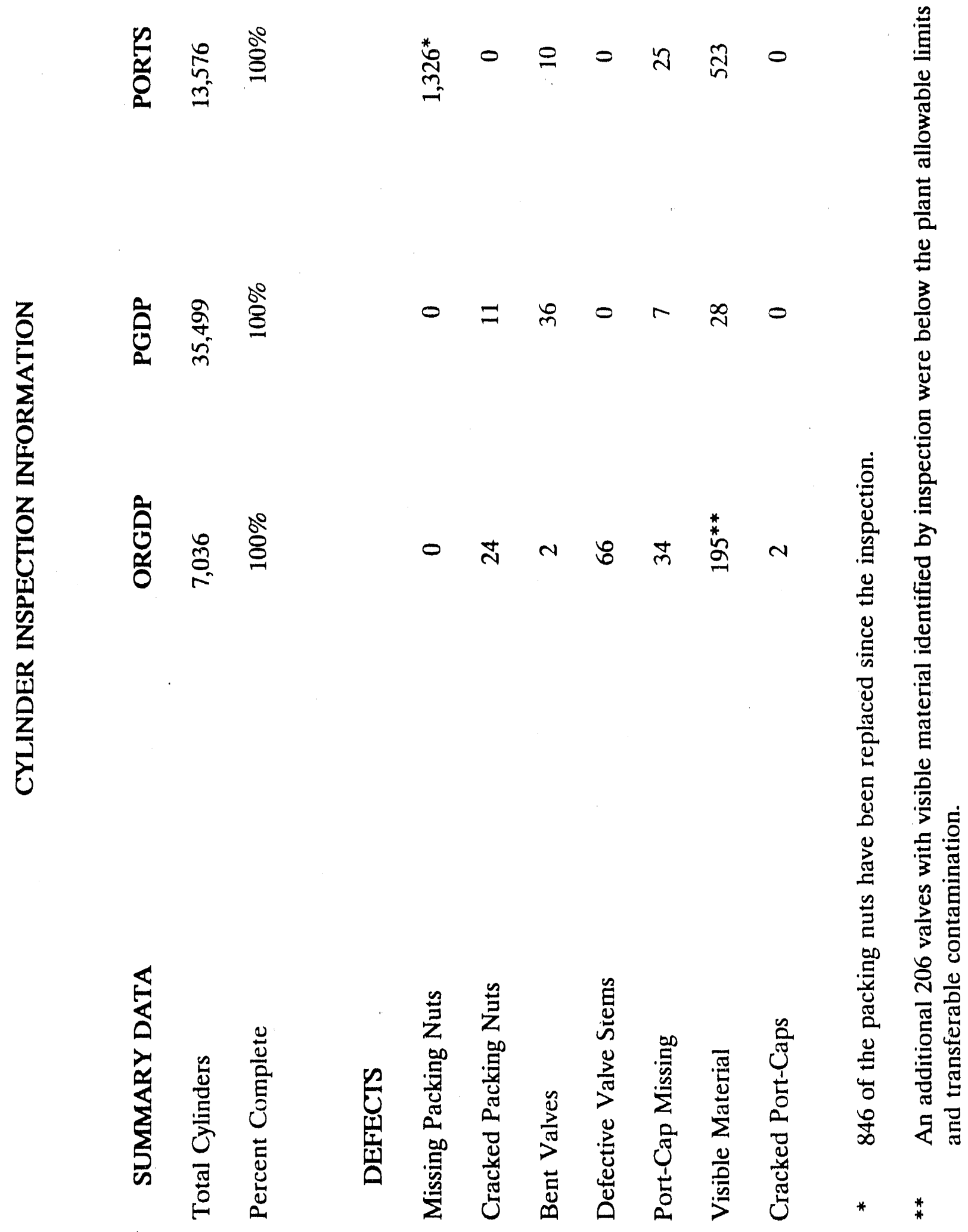


APPENDIX B

FOLLOW-UP ACTIVITIES ON CYLINDER YARD INSPECTIONS 


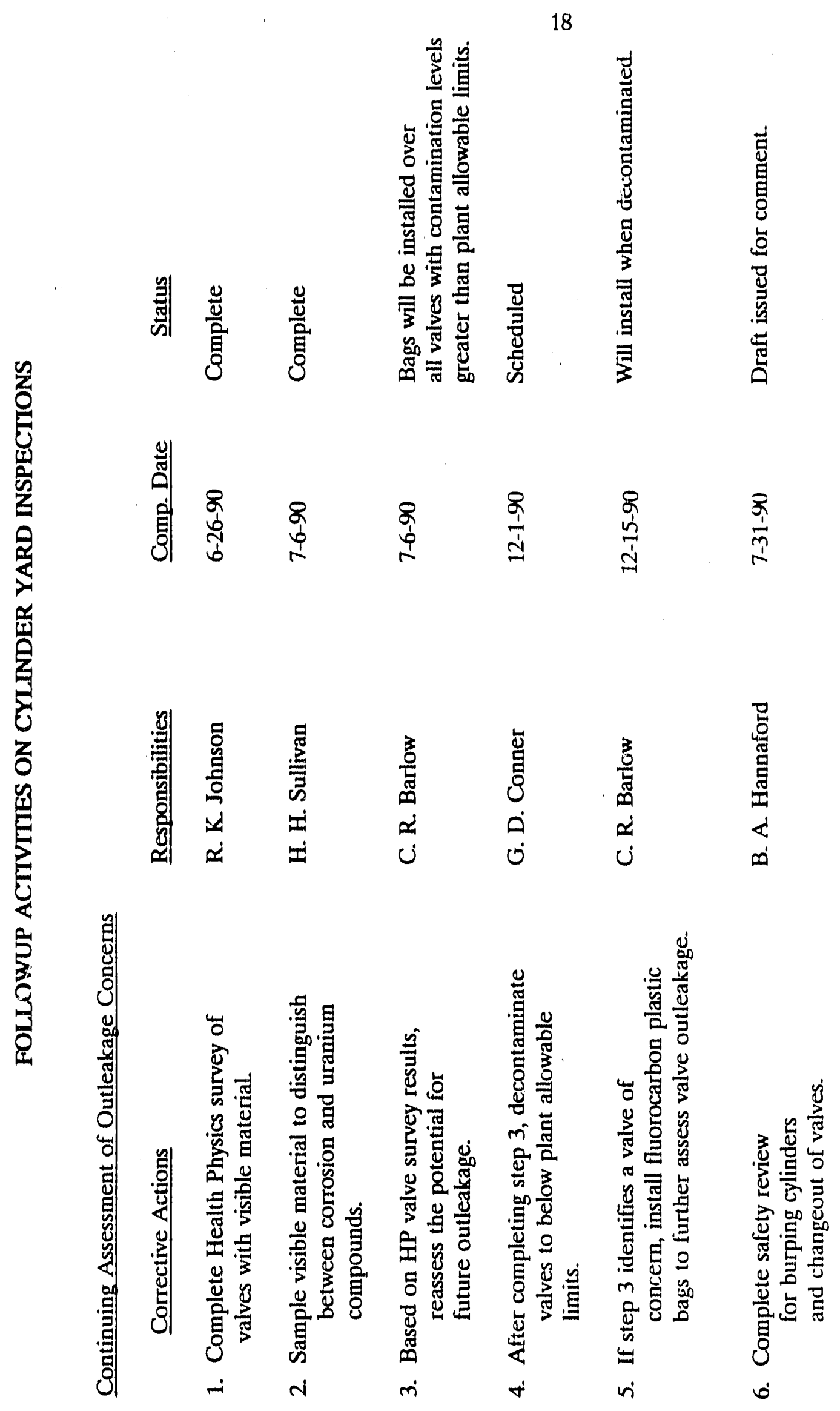




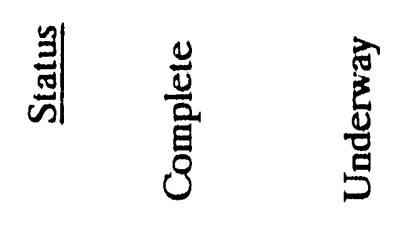

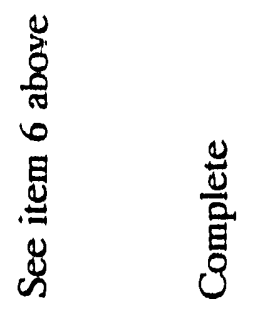

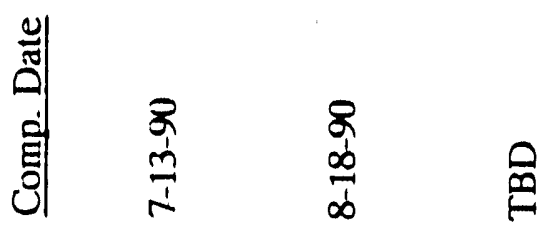

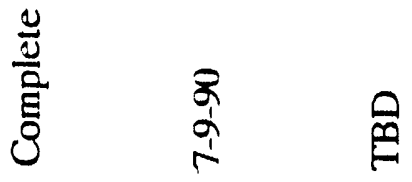

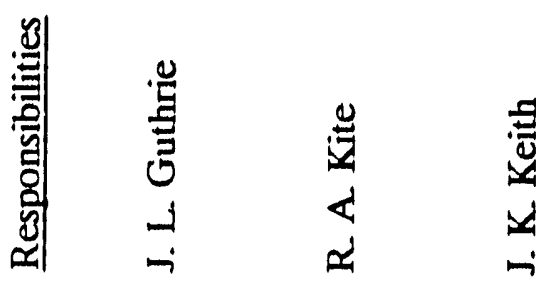

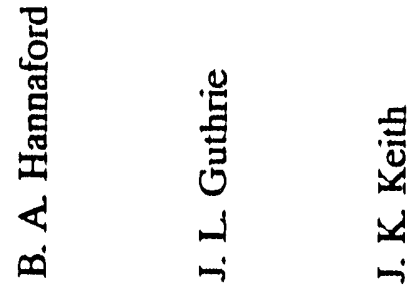
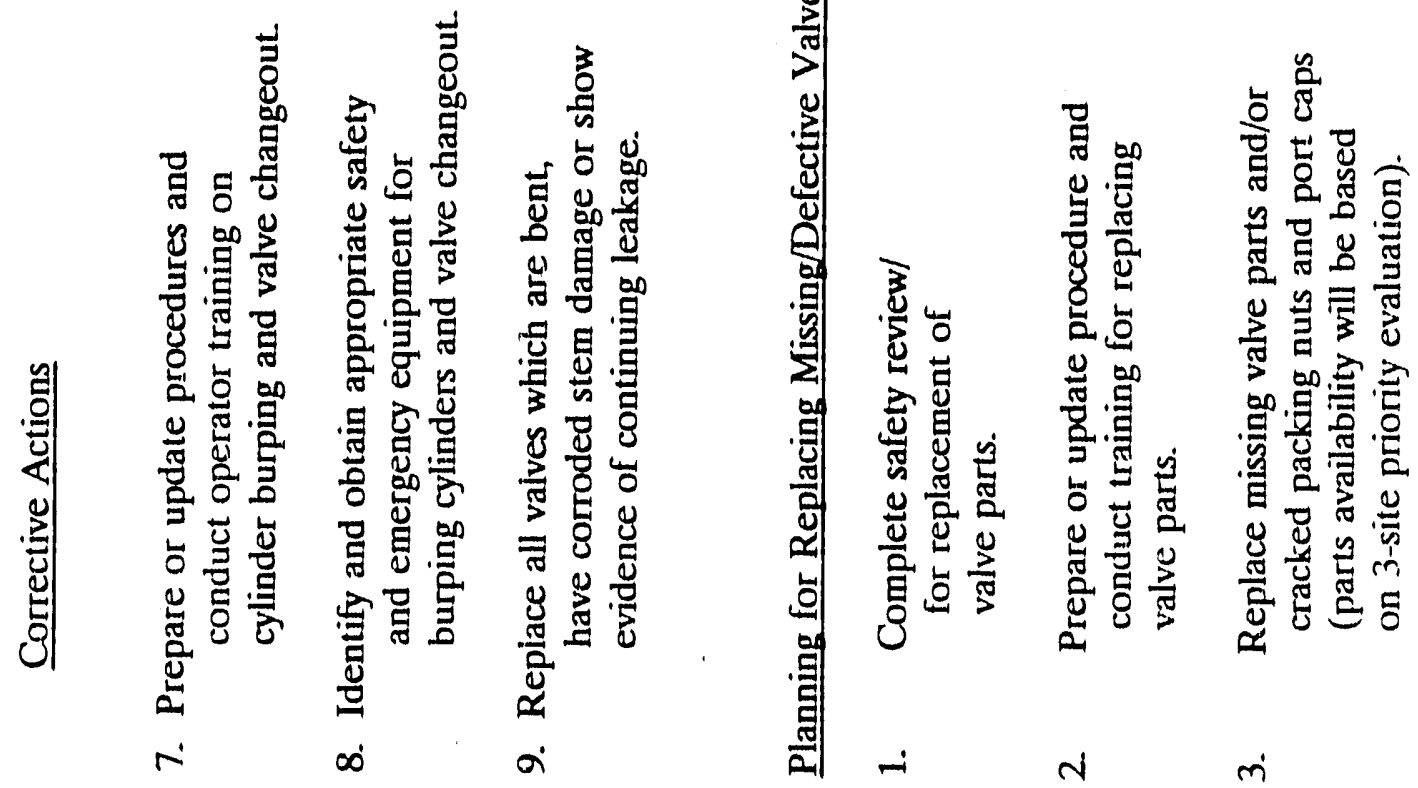
氙

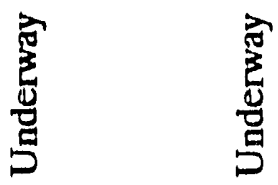

ํํํ.

है

क्र

$\theta$

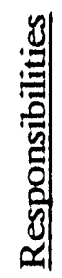
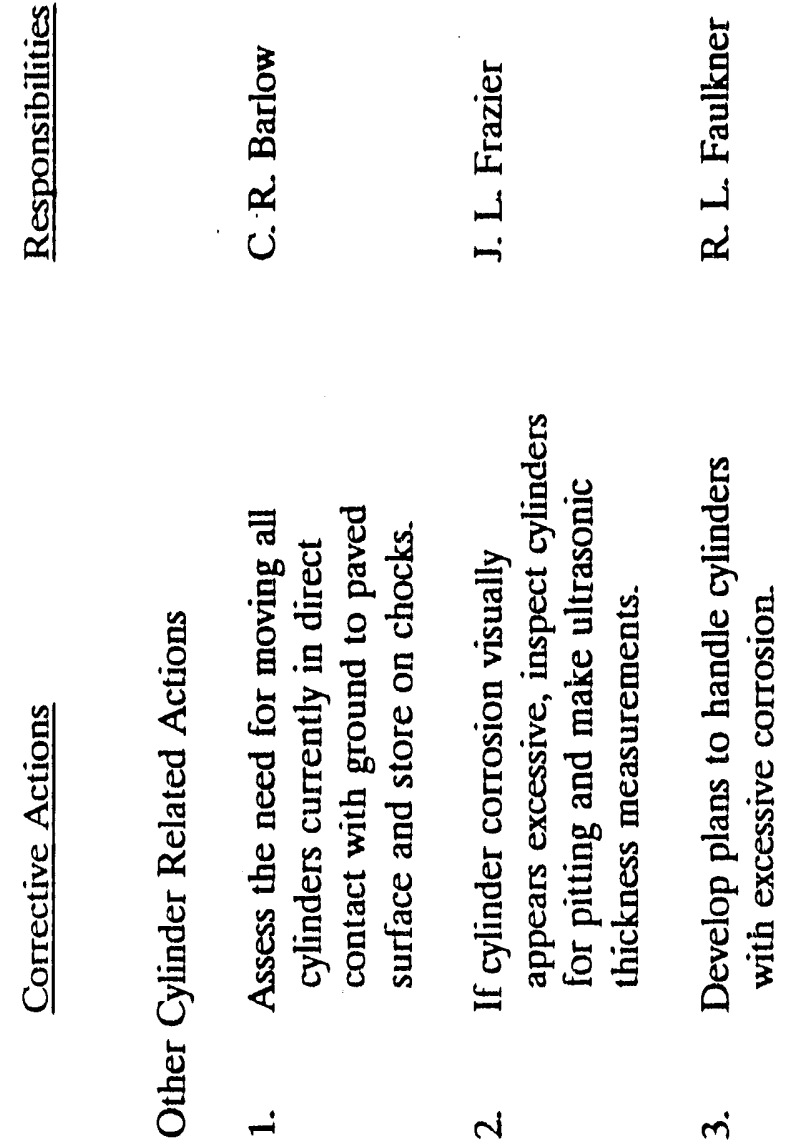
APPENDIX C

BRIEFING TO DOE ON CYLINDER YARD INSPECTIONS 

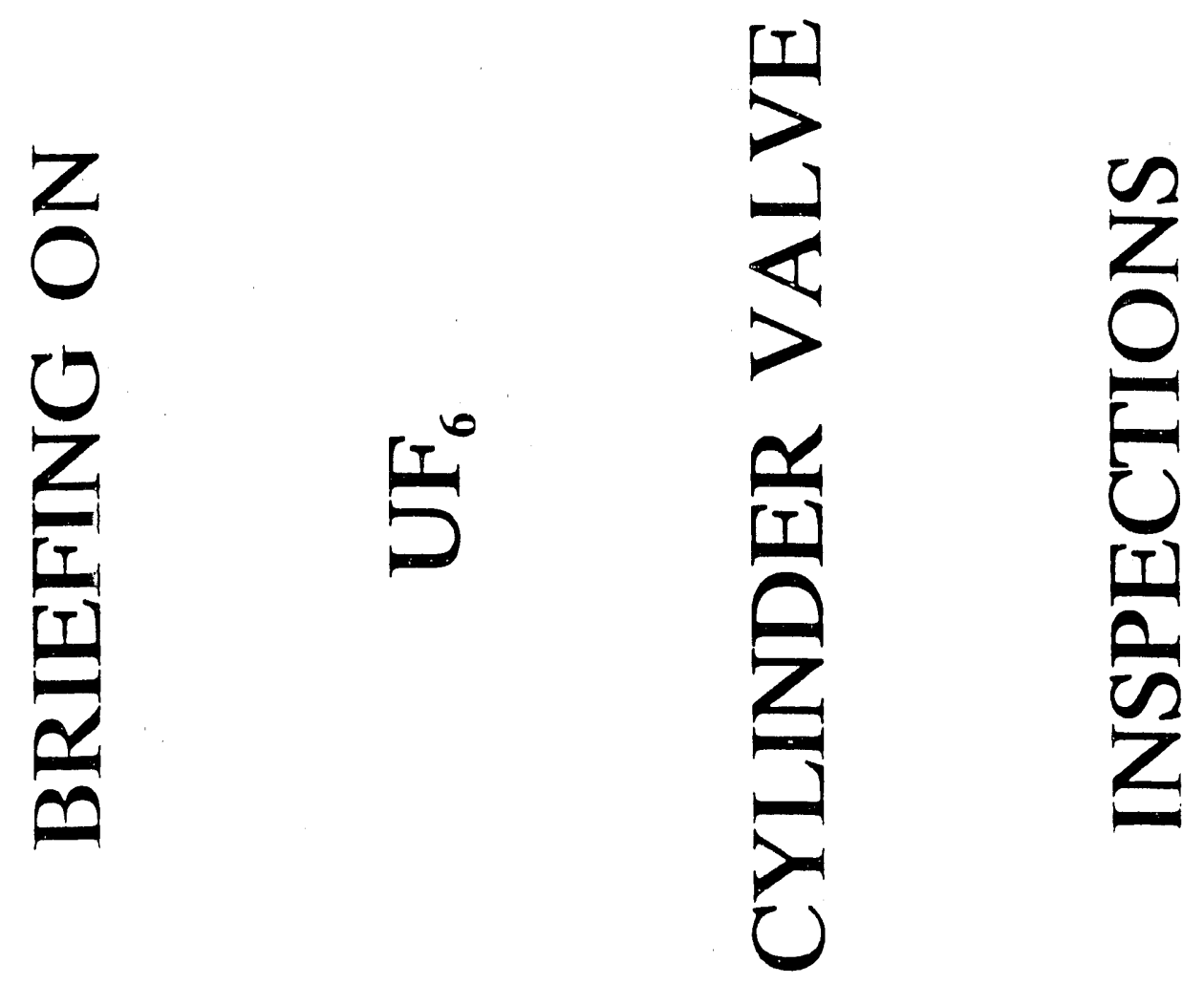


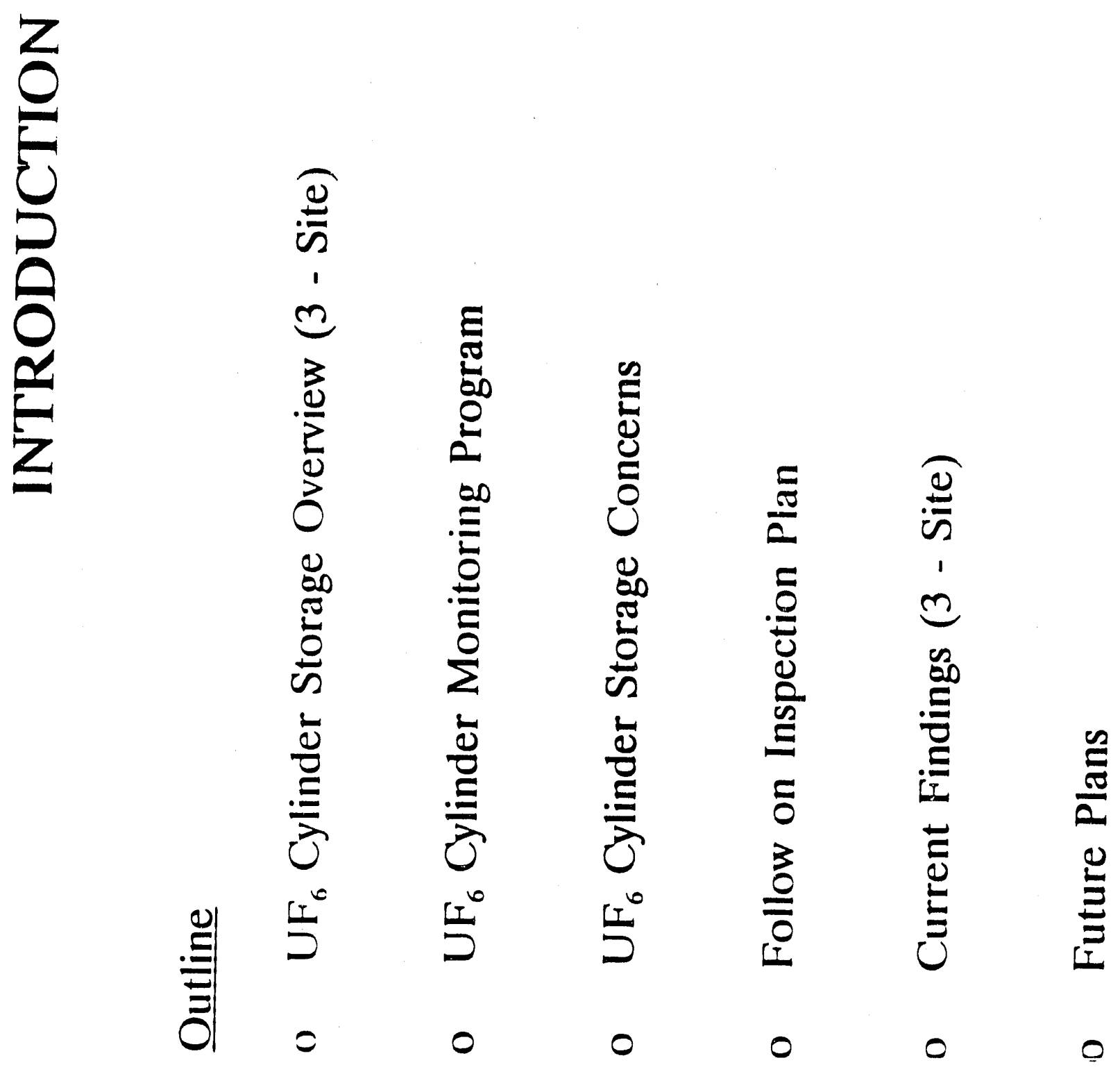




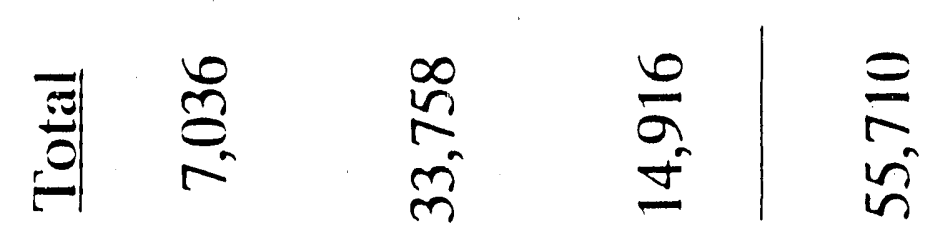

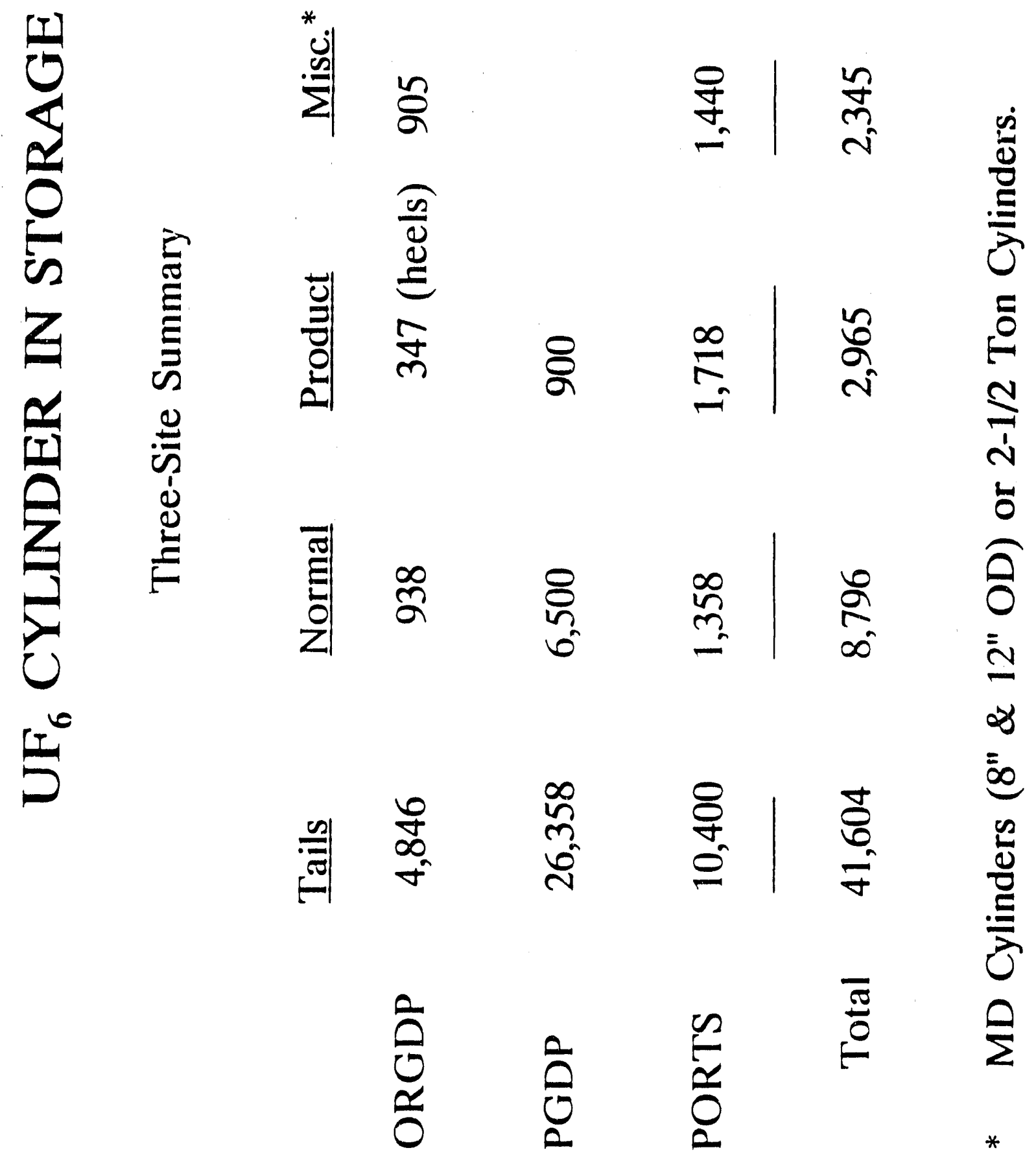




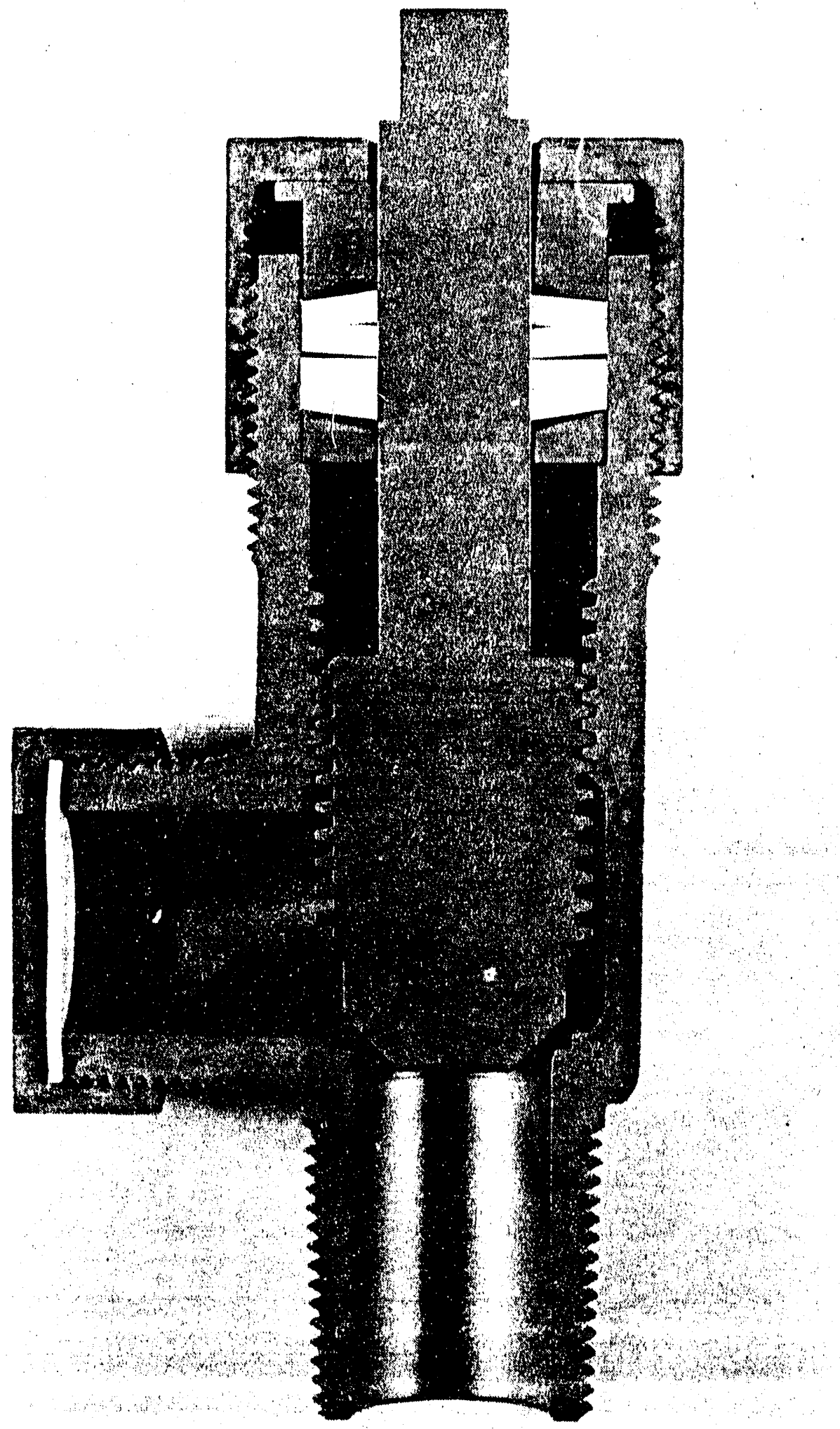

Sectional View of One-Inch Cylinder Valve 


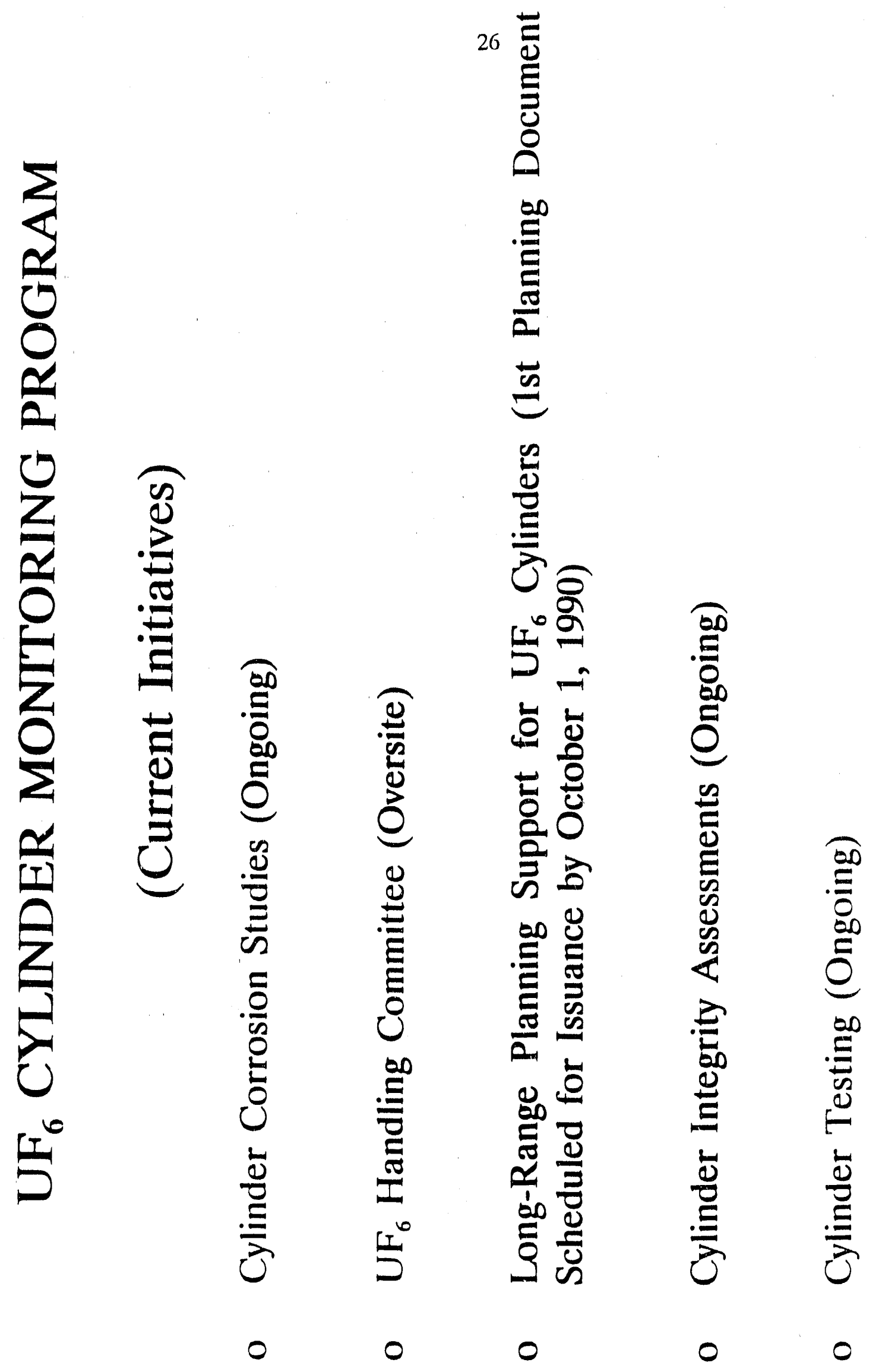



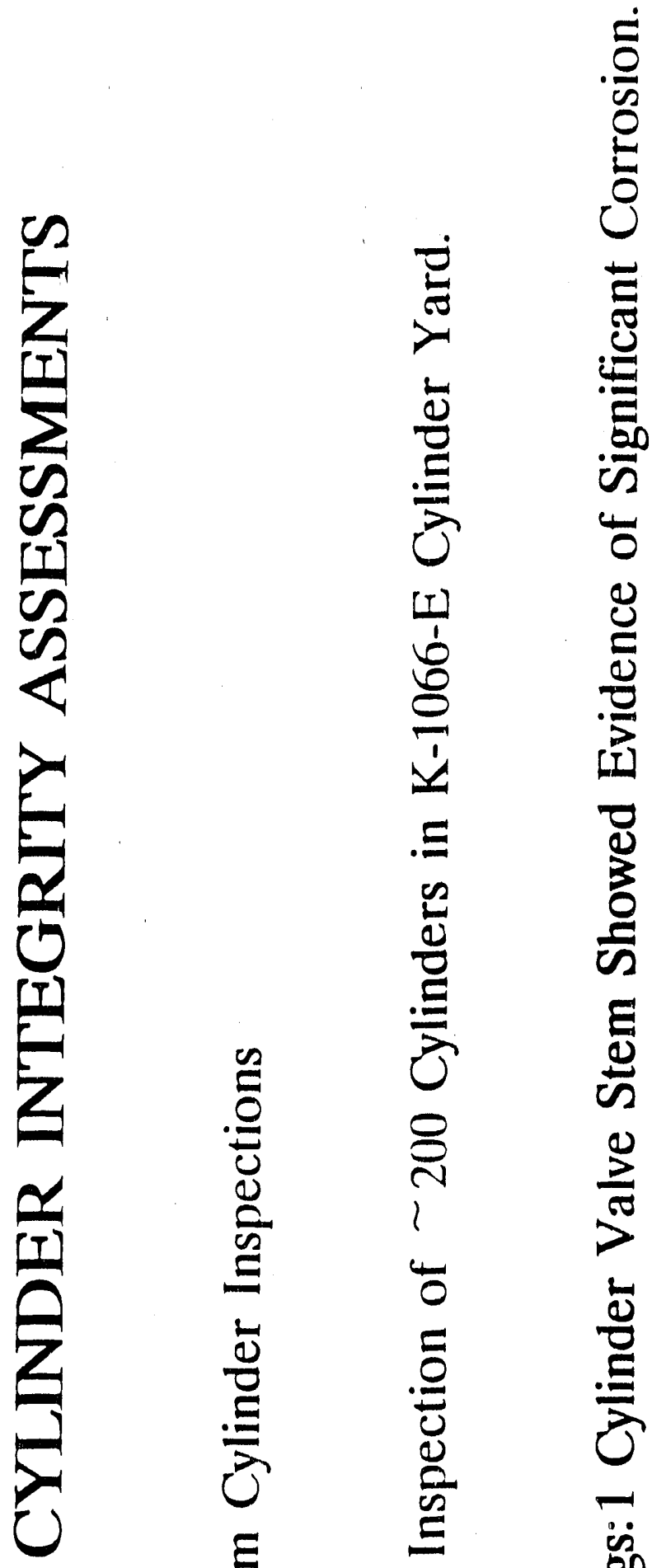

.$\Xi$

$\frac{\sqrt[c]{0}}{d}$

$\frac{2}{0}$

$\stackrel{2}{2}$

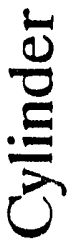

ฐิ

$\frac{0}{0}$

II

文

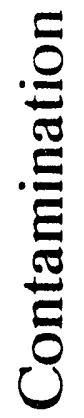

- 3

3

3

क

త్ర

인

ஓ

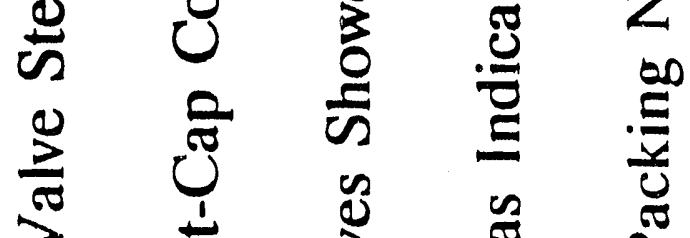

0
0
0
0
0
0

竎

冚

(1)

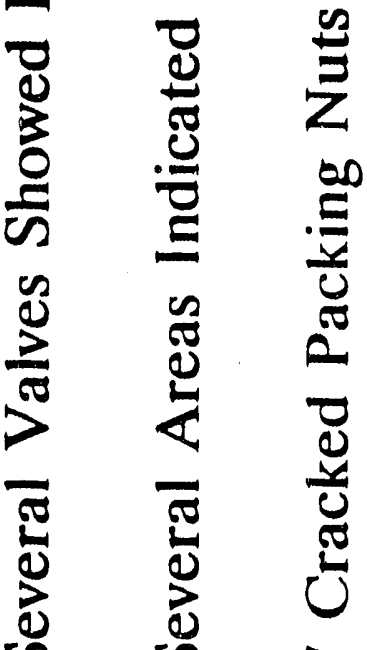

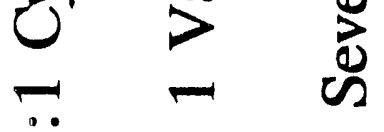

ธ

$N$

0

0

焉

0 


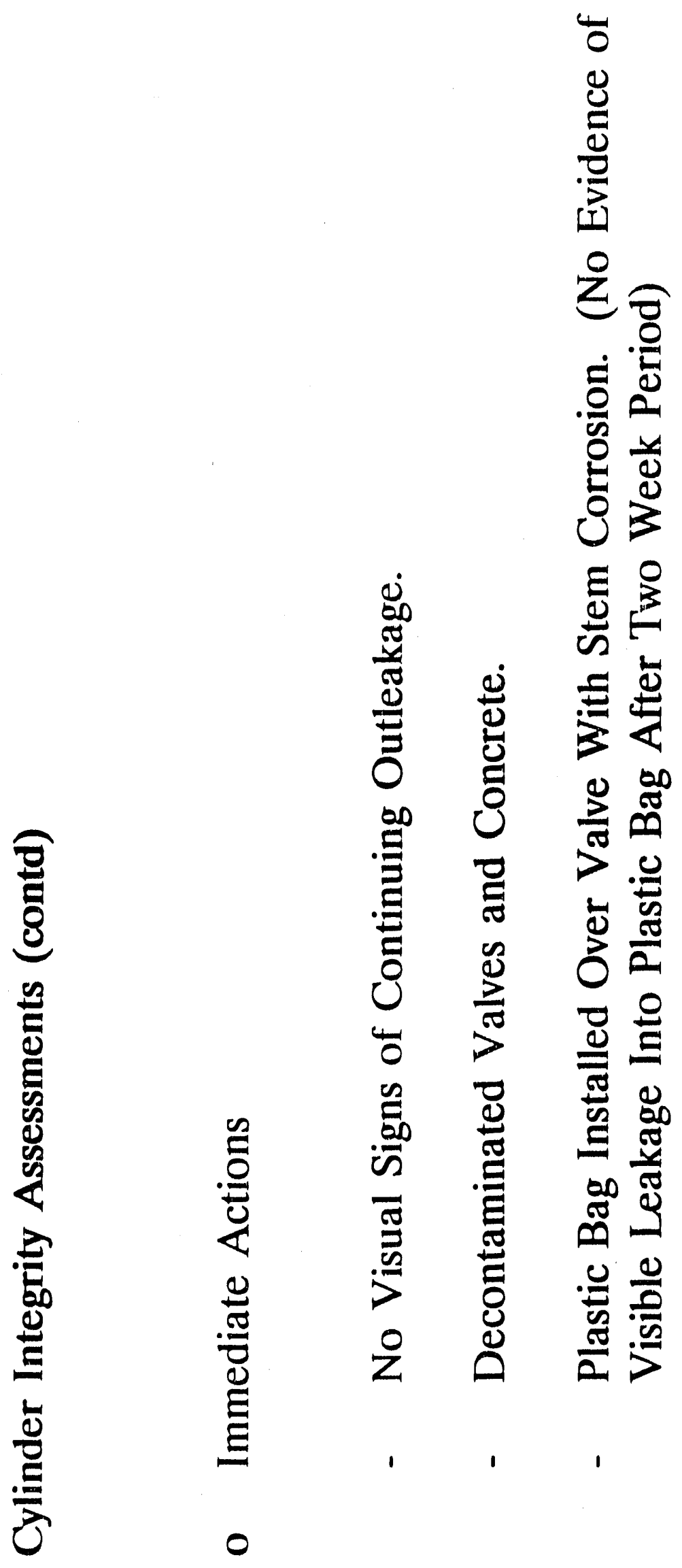




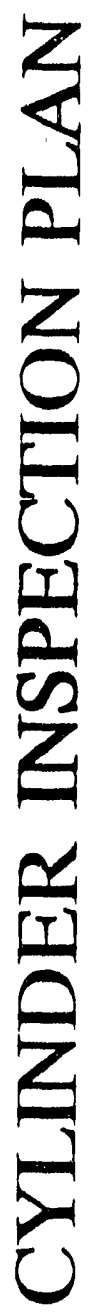

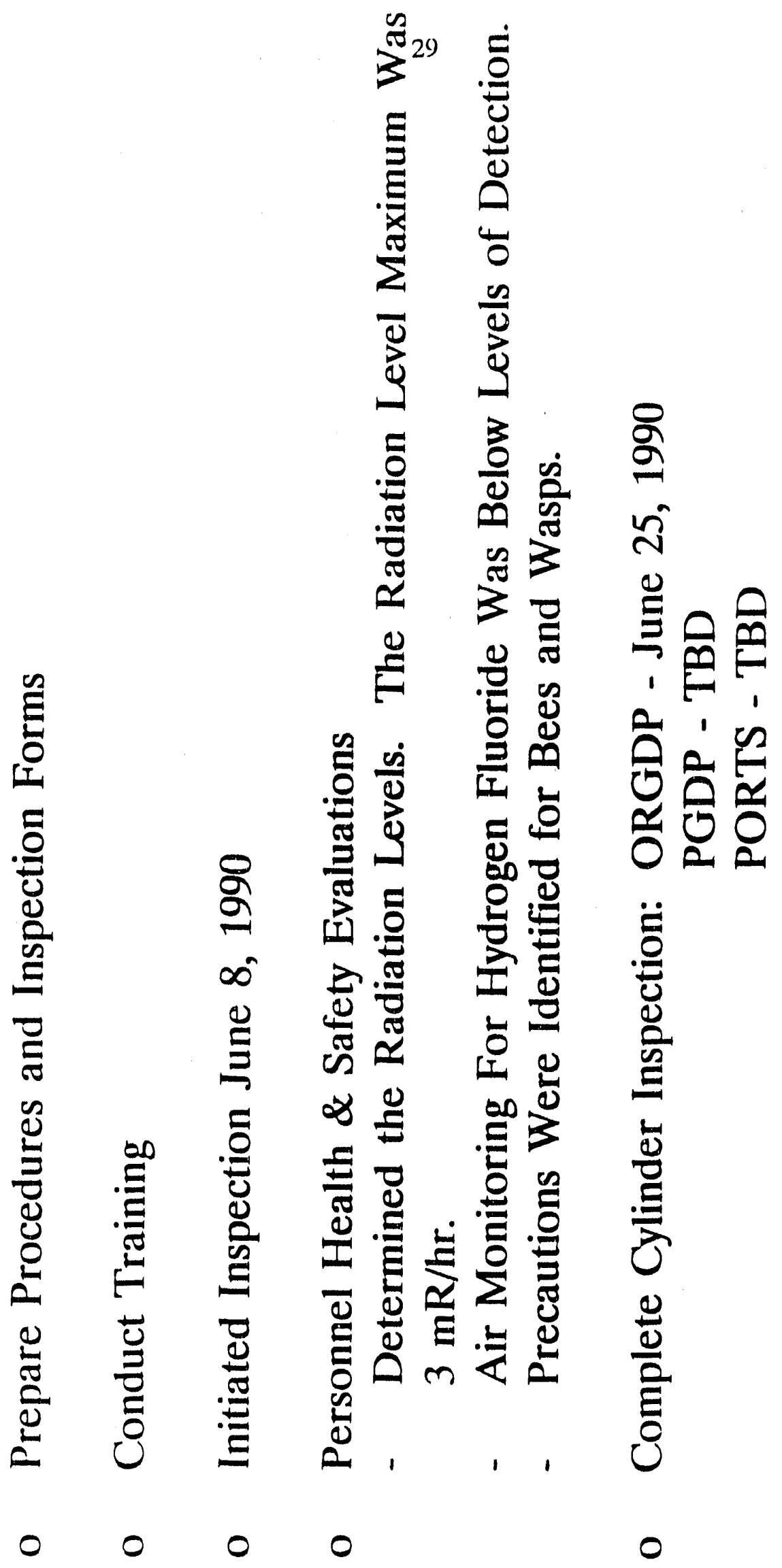




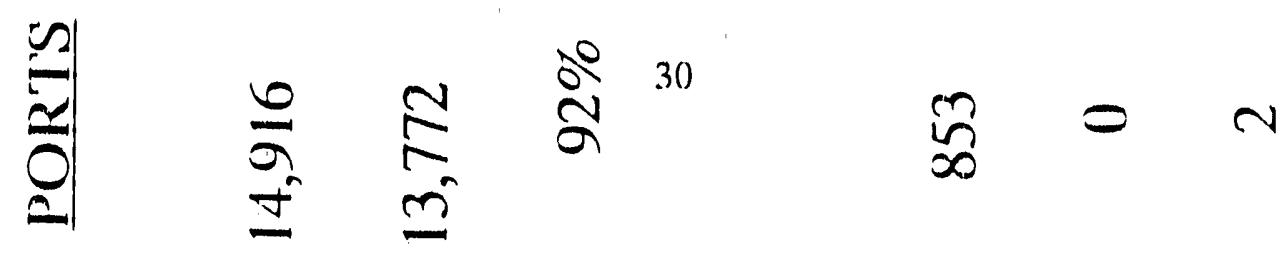

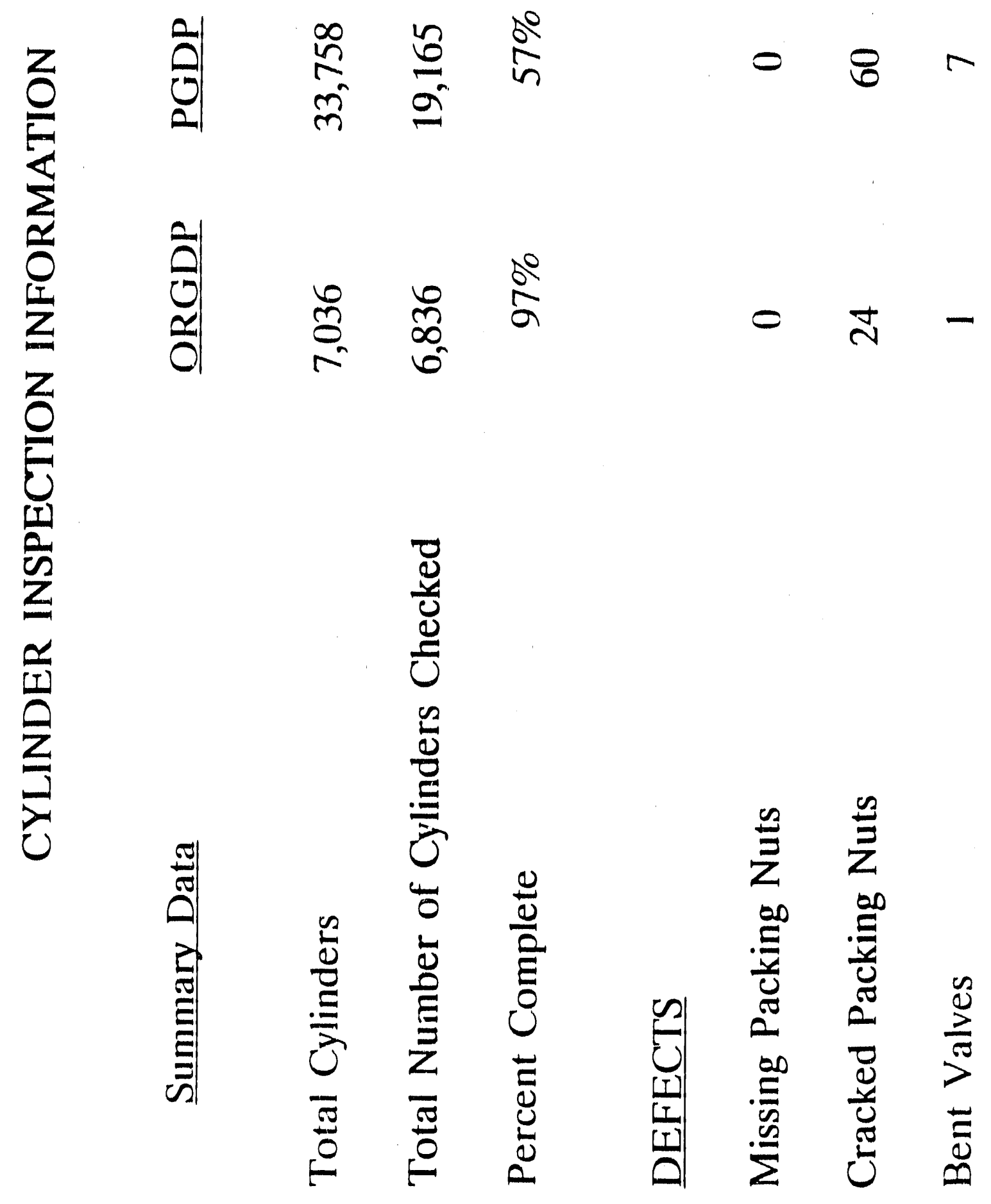




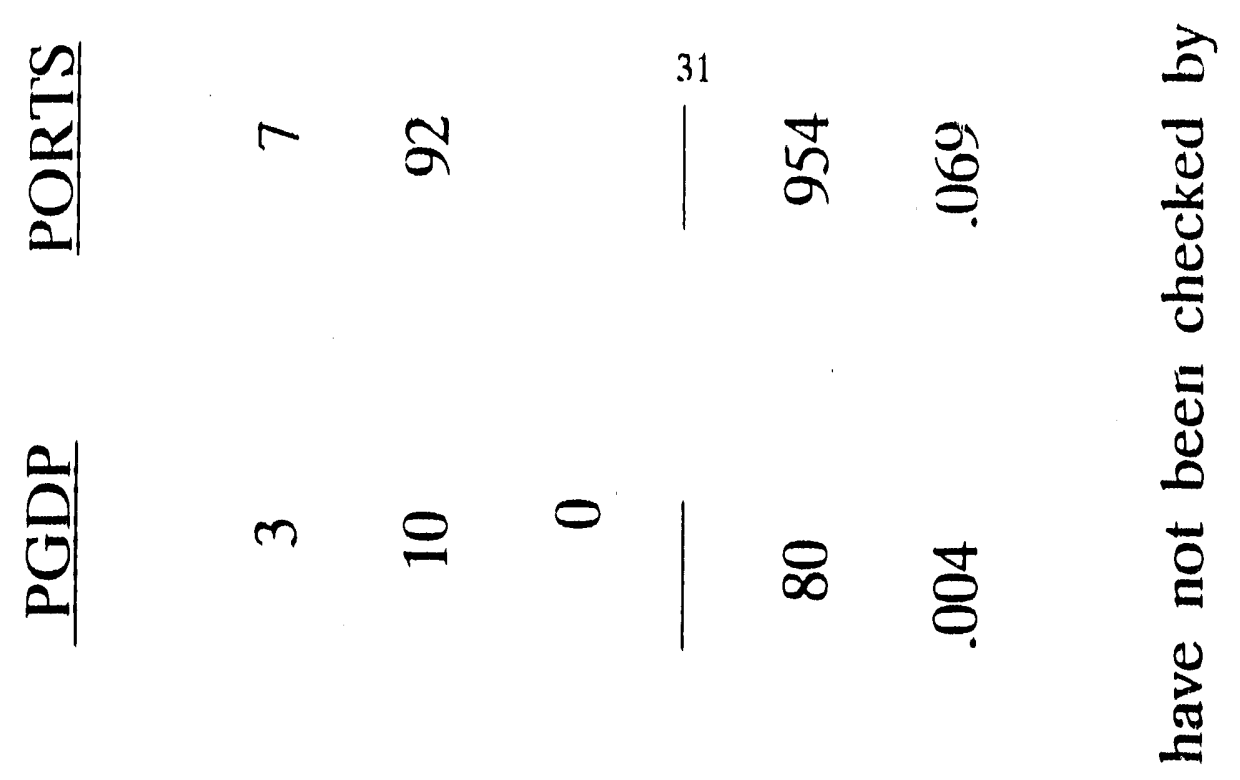

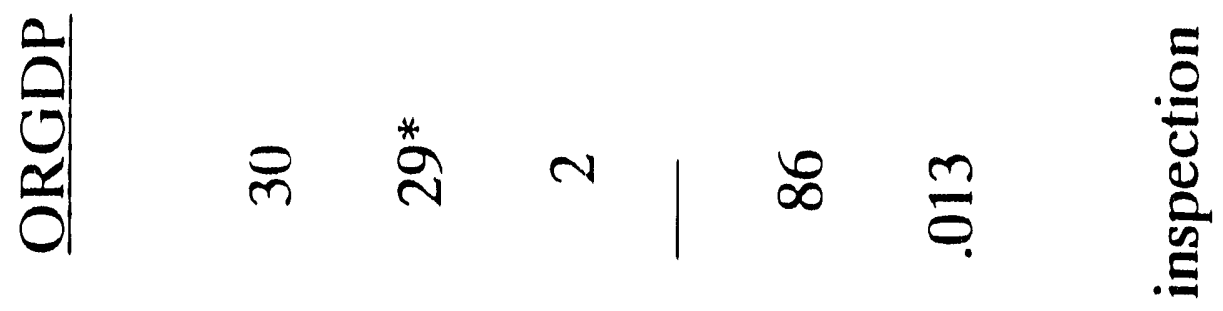

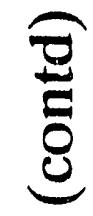

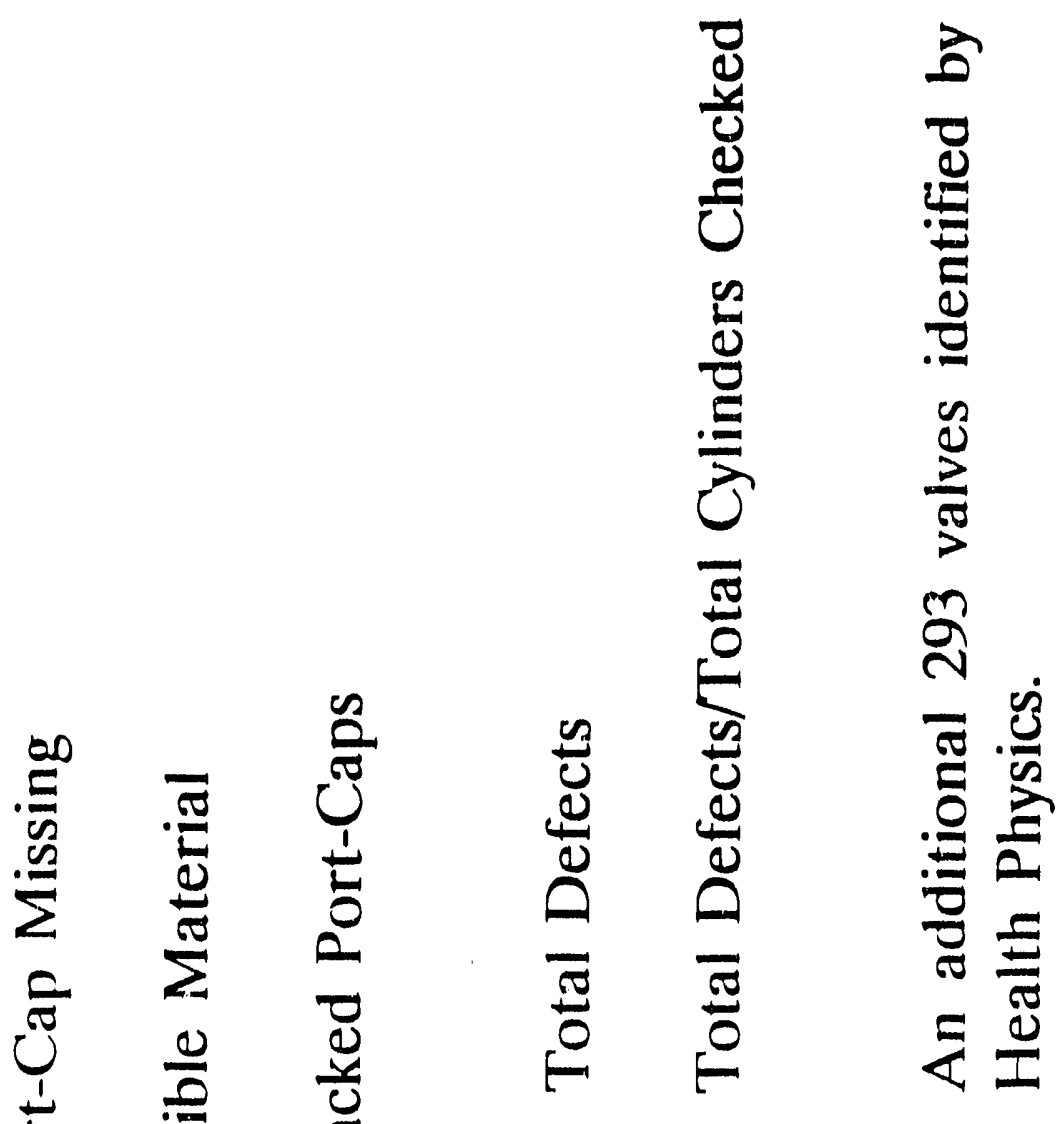

Eِ

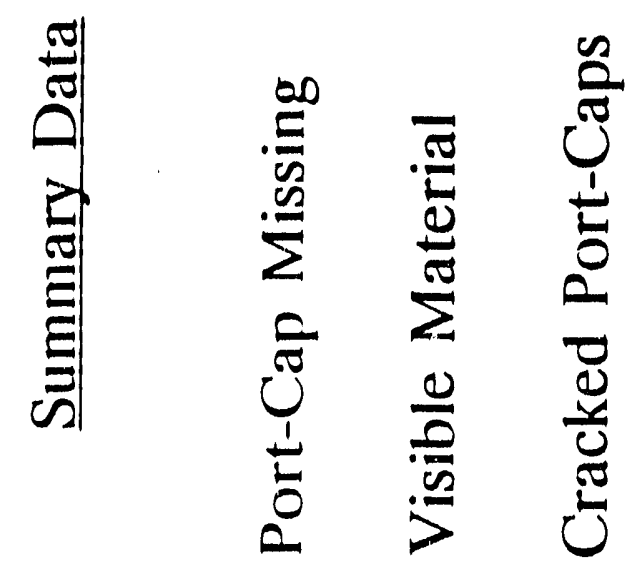

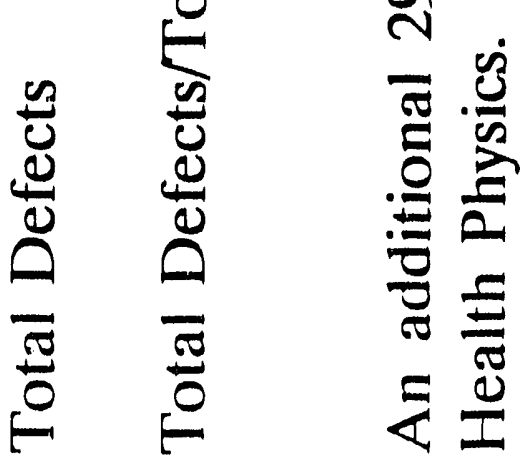



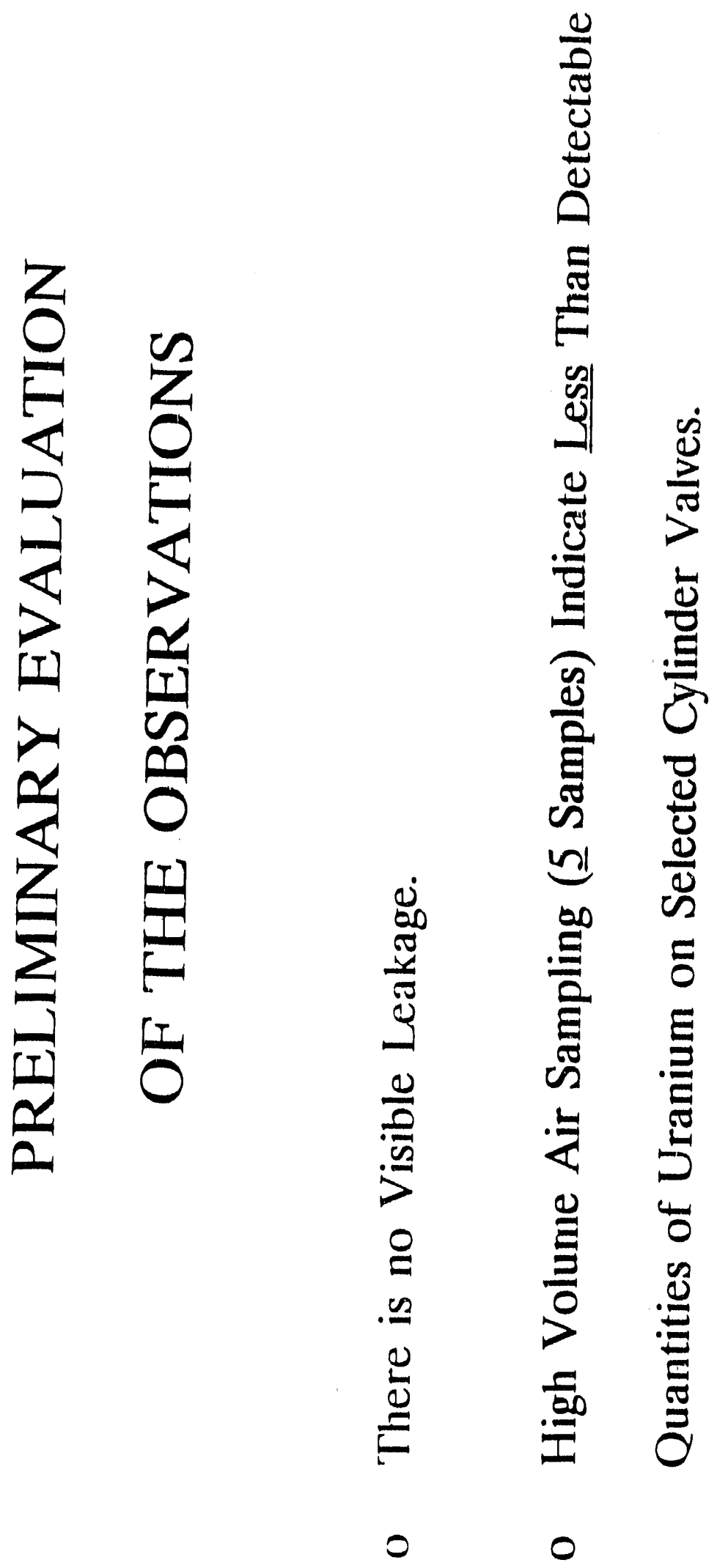


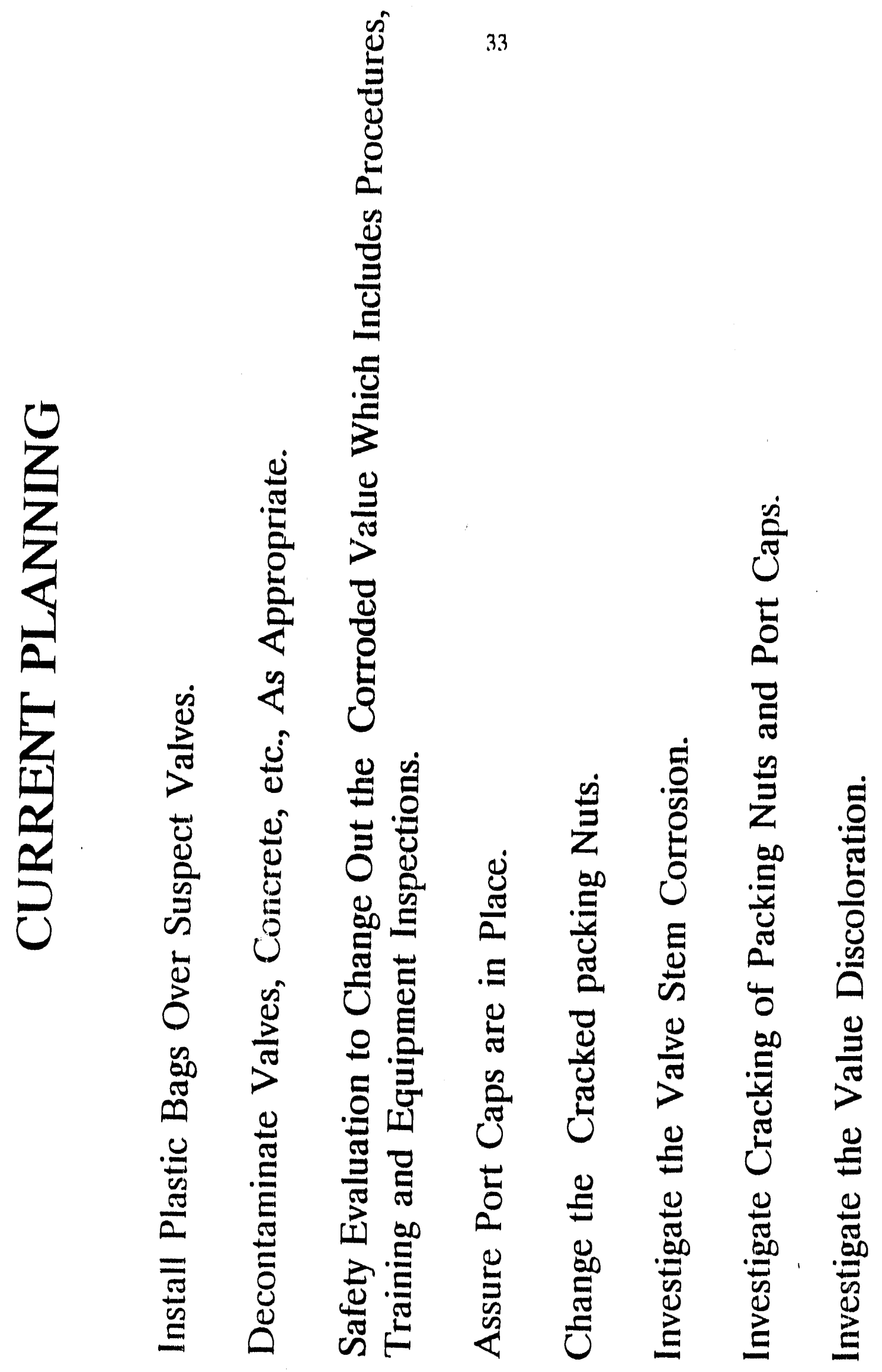




\section{DISTRIBUTION}

\section{Department of Encrgy-Oak Ridge Operations}

M. M. Hoiskell

R. O. Hultgren

J. Purks

J. R, Russell

Martin Marietta Energy Systems, Inc.

J. H. Alderson

C. R. Barlow

J. T. Bradbury

R. L. Faulkner

W. R. Golliher

R. L. Higgins

M. L. Jones

G. W. Lamb

T. R, Lemons

D. L. Mason

C. H. Peterson

J. E. Rushton

J. E. Shoemaker

W. E. Sykes

J. P. Vournazos

Y. W. Walton

H. D. Whitehead

Applied Technology Library

ORGDP Records Department - RC

MJB Technical Associates

K. T. Zichlke

$\underline{\mathrm{PAI}}$

W. A. Pryor 

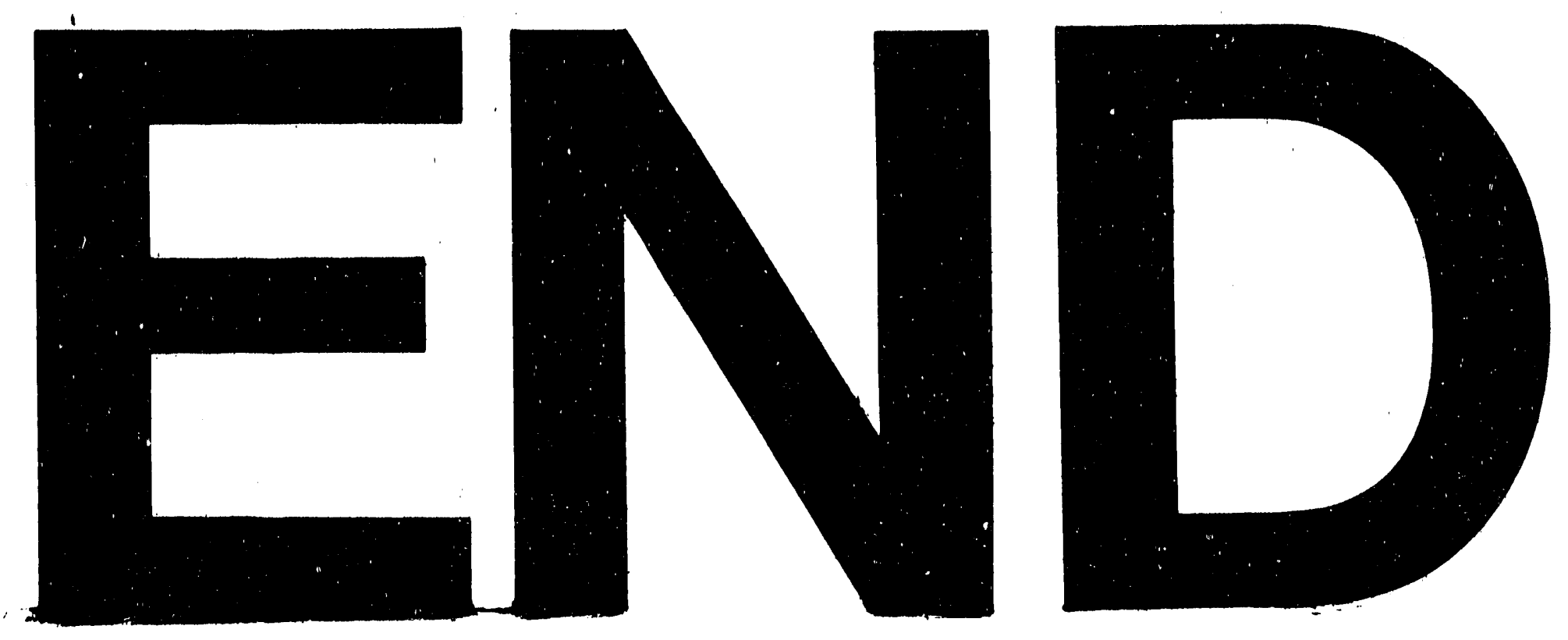

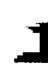

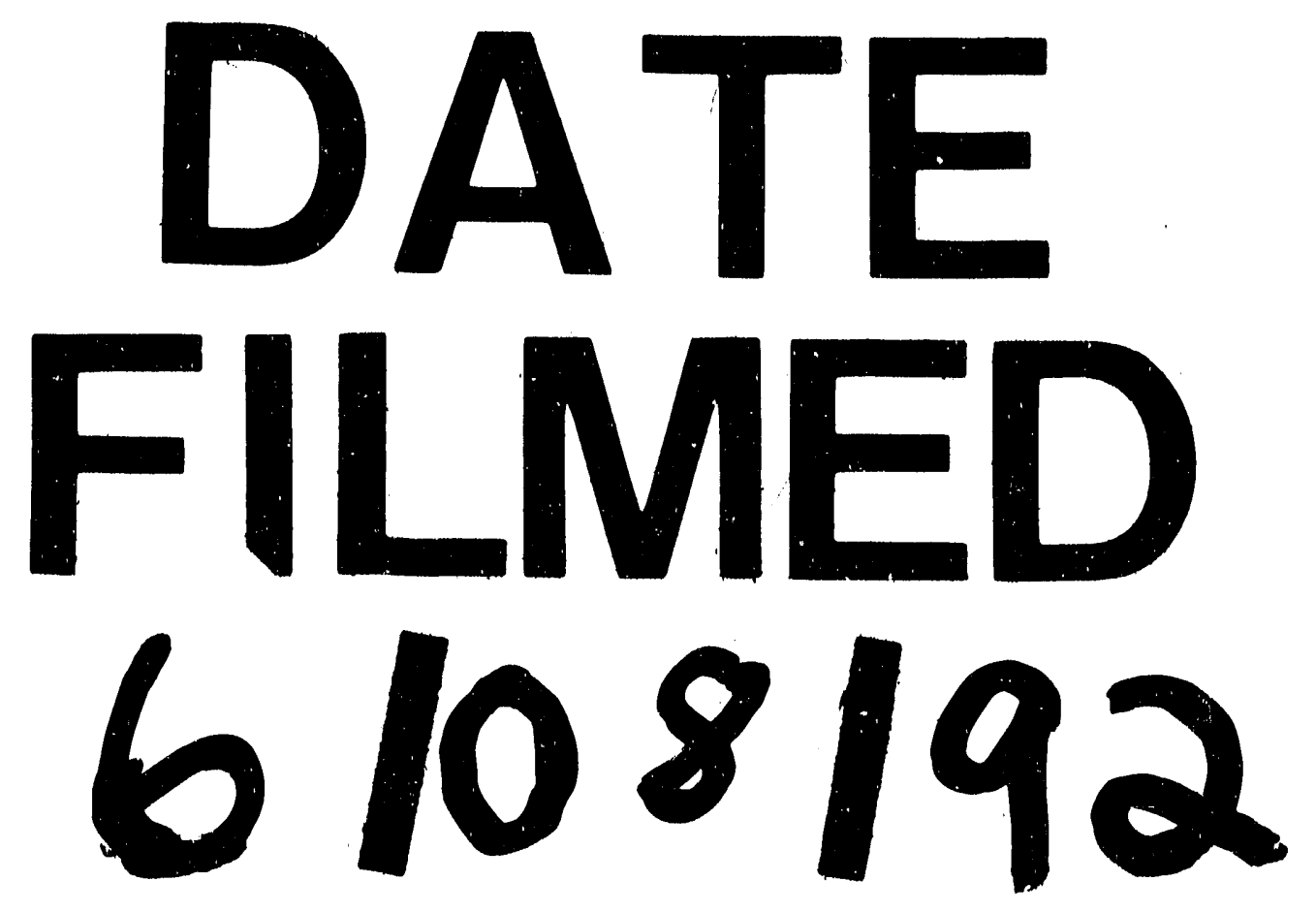

